Swarthmore College

Works

$10-1-2012$

\title{
Some Like It Hot, Some Like It Warm: Phenotyping To Explore Thermotolerance Diversity
}

C. H. Yeh

Nicholas J. Kaplinsky

Swarthmore College, nkaplin1@swarthmore.edu

C. $\mathrm{Hu}$

Y. Y. Charng

Follow this and additional works at: https://works.swarthmore.edu/fac-biology

Part of the Molecular Genetics Commons, and the Plant Biology Commons

Let us know how access to these works benefits you

\section{Recommended Citation}

C. H. Yeh, Nicholas J. Kaplinsky, C. Hu, and Y. Y. Charng. (2012). "Some Like It Hot, Some Like It Warm: Phenotyping To Explore Thermotolerance Diversity". Plant Science. Volume 195, 10-23. DOI: 10.1016/ j.plantsci.2012.06.004

https://works.swarthmore.edu/fac-biology/40

This work is brought to you for free by Swarthmore College Libraries' Works. It has been accepted for inclusion in Biology Faculty Works by an authorized administrator of Works. For more information, please contact myworks@swarthmore.edu. 


\title{
Some Like It Hot, Some Like It Warm: Phenotyping to Explore Thermotolerance Diversity
}

\author{
Ching-Hui Yeh ${ }^{1, \#}$, Nicholas J. Kaplinsky ${ }^{2, \#}$, Catherine $\mathrm{Hu}^{3}$, and Yee-yung Charng ${ }^{3,}$ \\ ${ }^{1}$ Department of Life Sciences, National Central University, Taiwan 32001, ROC \\ ${ }^{2}$ Department of Biology, Swarthmore College, Swarthmore, Pennsylvania 19081, USA \\ ${ }^{3}$ Agricultural Biotechnology Research Center, Academia Sinica, Taiwan 11529, ROC
}

\section{Abstract}

Plants have evolved overlapping but distinct cellular responses to different aspects of high temperature stress. These responses include basal thermotolerance, short- and long-term acquired thermotolerance, and thermotolerance to moderately high temperatures. This thermotolerance diversity' means that multiple phenotypic assays are essential for fully describing the functions of genes involved in heat stress responses. A large number of genes with potential roles in heat stress responses have been identified using genetic screens and genome wide expression studies. We examine the range of phenotypic assays that have been used to characterize thermotolerance phenotypes in both Arabidopsis and crop plants. Three major variables differentiate thermotolerance assays: 1) the heat stress regime used, 2) the developmental stage of the plants being studied, and 3) the actual phenotype which is scored. Consideration of these variables will be essential for deepening our understanding of the molecular genetics of plant thermotolerance.

\section{Keywords}

phenotyping; heat-shock protein; heat stress response; basal thermotolerance; acquired thermotolerance; functional genomics; heat stress regime

\section{Introduction}

Plants are sessile organisms which constantly experience changes in their environments. Some of these changes are stressful; they are detrimental to plant growth and development. Elevated temperatures result in complex and poorly understood effects on plant phenology [1] and cause plant heat stress. Heat stress significantly affects cellular homeostasis including both protein and membrane stability. To avoid or minimize the detrimental effect of heat stress, plants must respond appropriately to the challenges of stressful elevated temperatures. Much effort has been invested in understanding plant heat stress responses, efforts which have recently been motivated by concerns about potential decreases in crop productivity caused by global warming. It is optimistically believed with some justification

\footnotetext{
(c) 2012 Elsevier Ireland Ltd. All rights reserved.

"Corresponding author: yycharng@gate.sinica.edu.tw; FAX: 886-2-26515600.

\#Equal contribution.
}

Publisher's Disclaimer: This is a PDF file of an unedited manuscript that has been accepted for publication. As a service to our customers we are providing this early version of the manuscript. The manuscript will undergo copyediting, typesetting, and review of the resulting proof before it is published in its final citable form. Please note that during the production process errors may be discovered which could affect the content, and all legal disclaimers that apply to the journal pertain. 
that a better understanding of the mechanisms underlying plant heat stress responses may facilitate the development of technologies and breeding strategies for improving crop thermotolerance.

A large number of genes that are induced or repressed by heat treatment have been identified by transcriptome profiling using microarrays [2-10]. Demonstrating the functions of heat stress response genes using molecular genetic tools has become a bottleneck because of the large numbers of genes that have been identified. Isolating or generating genetic variants of target genes is time consuming and is not always fruitful as reverse genetic approaches often do not result in altered heat stress response phenotypes. For instance, in a study of $48 \mathrm{~T}$ DNA insertions in Arabidopsis genes implicated in heat stress response based on their expression profiles, only one gene had an acquired thermotolerance phenotype [11]. Although the function of some heat stress response genes may be obscured due to genetic redundancy, recent studies show that in many cases uncovering heat stress response phenotypes depends on choosing appropriate heat stress phenotype assays.

The difficulty in selecting appropriate phenotypes for characterization may have resulted in an underestimation of the complexity of the heat stress response in plants, since heat stress treatments performed in a laboratory are often simple and may not reflect 'real world' heat stress conditions. A number of environmental factors including, but not limited to, ambient air temperature and light intensity create a range of heat stress conditions that plants may experience during their lifetime [12]. These heat stress conditions can threaten the fitness and productivity of plants in combination with other stress factors, such as water limitation and high UV irradiation. Plants have evolved a complex heat stress response system to cope with these heat stress conditions. It is made up of overlapping subsets of genes required for thermotolerance in response to specific environmental conditions [13-16]. We will refer to these multiple kinds of responses as 'thermotolerance diversity'.

The concept of thermotolerance diversity suggests that phenotyping with only a few simplified thermotolerance assays may not be adequate for elucidating the functions of the large number of potential heat stress response genes identified in genomic studies. Instead a systematic phenotyping approach that includes a range of heat stress conditions may increase the chances of identifying the functions of potential heat stress response genes. Heat stress phenotyping can be performed at different temperatures, for various amounts of time, and with a range of heating devices, each of which has its own advantages and disadvantages. Choosing an appropriate phenotype to measure is critical because the function of a heat stress response gene may contribute to thermotolerance differentially across tissues and growth stages. Because these issues have not been discussed in detail in the plant heat stress response literature, we thought that it would be worthwhile to highlight and summarize these issues.

We summarize and discuss the phenotyping methods used in plant molecular genetic studies of heat stress response. To underscore the importance of phenotyping, we have not included an in depth discussion of the biological roles of heat stress response genes or signaling networks, which have been extensively reviewed elsewhere [17-24]. Instead we focus on critical parameters used in various thermotolerance assays. We also do not attempt to review the literature detailing phenological studies on temperature effects on crop yields, which is largely separate from the literature describing molecular genetic approaches to these questions. By focusing on the parameters used in thermotolerance assays we hope to provide a useful framework for designing future studies on plant heat stress response. This review is divided into two major sections; one focuses on the model plant Arabidopsis (Arabidopsis thaliana) in which many important molecular genetic discoveries have been made. The 
second section focuses on heat stress phenotyping in crop plants. Finally we briefly discuss related issues in emerging model plant functional genomics systems.

\section{Phenotyping methods for studying heat stress response in Arabidopsis}

Arabidopsis is the most widely used species for plant molecular genetics. The history and advantages of its use as a model system for molecular genetics has been comprehensively described [25] and this simple plant has been extensively used to study the complex heat stress response in plants [18]. Knowledge gained from Arabidopsis research serves as a reference point for work in other plant species including economically important crops.

Organismal thermotolerance is the most widely used phenotype for describing the biological functions of heat stress response genes. Thermotolerance functions of a heat stress response gene were first described in an Arabidopsis study using transgenic plants overexpressing HSFA1A (or HSF1, a transcription factor) and HSFA1A/GUS fusion proteins [26]. The heat stress regimes and heating device used for determining basal and acquired thermotolerance levels were clearly described. This study showed a dramatic difference in the viability of wild-type vs. transgenic seedlings after the heat stress treatments. In our survey of the field, viability is the most frequently reported output trait used to describe thermotolerance in studies using Arabidopsis seedlings (Table 1).

The size of Arabidopsis seedling is small enough so that a large number of seedlings can be grown and heat-treated in a single petri dish, which increases the throughput of experiments. Additional output traits such as hypocotyl elongation and chlorophyll accumulation have also been successfully employed to efficiently identify mutagen-induced Arabidopsis mutants with thermotolerance defects [27, 28]. New heat stress regimes were also adopted to study heat stress-related genes in both forward and reverse genetic studies [29-31]. In the following sections we summarize and discuss three major parameters that need to be considered for heat stress response phenotyping: the heat stress regime, the developmental stage of the plant to be studied, and the thermotolerance-associated output trait. The last two parameters are often considered simultaneously so we will discuss them in one section.

\subsection{Selection of heat stress regime and heating device}

The heat stress regime used in an experiment is critical for successfully identifying thermotolerance phenotypes. Several distinct heat stress regimes have been developed for characterizing the phenotypes of Arabidopsis T-DNA knockout (KO) mutants. These regimes have uncovered functional specificities of heat stress response genes in different types of thermotolerance [11, 14-16, 30]. Four major thermotolerance types can be categorized based the heat stress regimes used in these studies: basal thermotolerance (BT), short-term acquired thermotolerance (SAT), long-term acquired thermotolerance (LAT), and thermotolerance to moderately high temperatures (TMHT; Table 1). The heat stress regimes used to assay these types of thermotolerance are shown schematically in Figure 1A. Minor differences in temperature and treatment duration are found in different studies, presumably due to differences between the heating devices, the genetic backgrounds, and the growth conditions used in each experiment.

Three types of heating device have been employed in Arabidopsis thermotolerance studies: heating blocks, water baths, and growth chambers/ovens (Table 1). For seedlings grown in petri dishes water baths seem to be the most efficient of the three to deliver heat stress temperatures. It takes less than $45 \mathrm{~min}$ at $44^{\circ} \mathrm{C}$ to kill non-acclimated wild-type Col-0 seedlings in a sealed petri dish submerged in water bath, while more than $1 \mathrm{~h}$ at $45^{\circ} \mathrm{C}$ is required on heating block or in growth chamber to do the same (Table 1). This difference is presumably due to the better thermal conductivity of water than air. 
Water baths are appropriate for short-term high temperature treatments performed in the dark to avoid the complex effect of phototoxicity. If heat stress treatment in the light is needed, such as in TMHT, a growth chamber is the most commonly used approach for delivering a heat stress. Maintaining temperature stability temporally and spatially in a growth chamber is a significant problem for generating reproducible results. Caution in preventing uneven heating in growth chambers must be used to avoid heat stress gradients across and between plates. The door of the chamber should be kept closed as much as possible and petri dishes should be placed directly on a large pre-equilibrated heat sink such as a block of metal. Although a heating block with an appropriate light source can also be used this approach, it has not commonly been used for heating petri dishes in heat stress response studies.

BT is the ability of a plant to tolerate heat stress, generally $44-45^{\circ} \mathrm{C}$ for Arabidopsis seedlings, without acclimation, a prior exposure to moderately high temperatures. BT has been measured at temperatures as low as $30^{\circ} \mathrm{C}$ with durations up to $5 \mathrm{~d}[32]$ or $38^{\circ} \mathrm{C}$ for $16 \mathrm{~h}$ [33]. Heat acclimation at moderately high temperature induces the synthesis of many heat shock proteins (HSPs) and leads to enhanced tolerance to severely high temperature, which is named acquired thermotolerance. Prolonged exposure to moderately high temperatures induces some HSPs and thermotolerance against these conditions is probably different from BT or acquired thermotolerance. Instead, we proposed that this type of thermotolerance needs to be separately classified as TMHT, as it is distinct from acquired thermotolerance associated with a challenge at severely high temperature. This difference is nicely illustrated by a recent study on a mitochondrial co-chaperone in the DnaK/HSP70 complex, MGE2. MGE2 is required for tolerance to prolonged exposure to $35^{\circ} \mathrm{C}$ for up to $9 \mathrm{~d}$, but not for either basal or acquired thermotolerance associated with acute heat stress conditions at $44^{\circ} \mathrm{C}$. By contrast, HSPs that are involved in basal and acquired thermotolerance such as HSP101 play a minimal role in TMHT [15]. These data indicate a mechanistic difference between the thermotolerance required for survival under moderate and severe heat stress conditions. Although these modes of thermotolerance appear to be experimentally separable, there is evidence for at least a limited overlap in the plant response mechanisms. A genetic screen designed to identify genes involved in TMHT resulted in the isolation of the heat-intolerant (hit) mutants [29]. HIT2 encodes a nuclear export receptor XPO1A that is required for BT and TMHT but not for acquired thermotolerance [16]. This observation suggests that some heat stress response genes are involved in tolerance both to chronic and certain mode of acute heat stress.

The recent identification and characterization of the heat stress-associated $32-\mathrm{kD}$ protein (HSA32) expands the assays for acquired thermotolerance phenotypes that need to be considered when thinking about plant heat stress response [30]. HSA32 is required for LAT, a term which first appeared in [34]. The heat stress regime for LAT includes a long recovery period (48-72 h) between the acclimation treatment and the high temperature challenge. This is in contrast to the short recovery time (usually less than $2 \mathrm{~h}$ ) in the heat stress regime used for acquired thermotolerance assay in many studies (Fig. 1A). To distinguish LAT from the acquired thermotolerance associated with a short recovery time, we have renamed the latter SAT [15]. The heat stress challenge in a LAT regime is less severe than for SAT (Fig. 1) because acquired thermotolerance gradually decays after a long recovery [30]. The LAT heat stress regime that revealed the mutant phenotype of HSA32 T-DNA KO plant is also effective in identifying LAT phenotypes in KO mutants of HSFA2 [11], ROF1 [34], and ROF2 [35]. LAT has only been reported in studies using Arabidopsis. It remains to be demonstrated that this type of thermotolerance exists in other species although this seems likely since the genes involved in LAT responses are conserved among land plants [36]. 
Another variable in heat stress regimes is how acclimation is performed. Gradual acclimation by continuously increasing temperature from $22^{\circ} \mathrm{C}$ to $45^{\circ} \mathrm{C}$ over a period of $6 \mathrm{~h}$ (Fig. 1B) leads to higher thermotolerance levels and higher expression of heat stress response genes than a typical step-wise sudden acclimation [31]. The presence or absence of a recovery period between acclimation and heat stress challenge must also be considered [37]. A recovery period at non-stress temperature after acclimation treatment results in higher thermotolerance levels, probably due to sufficient time elapsing allowing for HSP accumulation [37]. It is to be seen whether these heat stress regimes are associated with novel types of thermotolerance.

The functional specificities of heat stress response genes in different types of thermotolerance cannot simply be predicted by transcript profiles. Instead, a better correlation between phenotype and protein levels was shown in some cases [15, 30]. It may be helpful first analyze the protein profiles of genes of interest to determine the kinds of heat stress regimes needed to uncover heat stress response phenotypes.

\subsection{Selection of growth stage and output traits}

Arabidopsis has distinct developmental stages that should be assayed separately for thermotolerance phenotypes [38]. Thermotolerance phenotypes of seeds, seedlings, adult plants, reproductive organs, and detached leaves have been determined in various experiments (Table 1). Since tissues assayed at different growth stages have varied levels of thermotolerance $[13,39,40]$ heat stress regimes have to be carefully designed to account for plant age. When characterizing the thermotolerance phenotypes of either a new mutation or a transgene the possibility of developmental phenotypes should be carefully evaluated to avoid confusing the thermotolerance effects due to altered growth with true changes in cellular thermotolerance. The extended recovery period before the final, severe, heat stress in LAT assays provides a long window for changes in development to affect BT, so special caution should be taken in these experiments to rule out developmental effects. One also needs to consider whether and to what extent any acclimation treatment may differentially retard growth among genotypes. Finally, in order to reveal the effect of acclimation any heat stress challenge measuring SAT or LAT must be severe enough to overcome BT at any relevant stage of development.

Arabidopsis seeds, which contain high levels of HSPs, can tolerate more than $2 \mathrm{~h}$ at 44 $45^{\circ} \mathrm{C}$ after 3-d of imbibition at $4^{\circ} \mathrm{C}$ without acclimation, which is considered as BT. The rate and extent of germination are easy and reliable phenotypes that can be assessed after the heat treatment. To our knowledge no report has been published on the thermotolerance of dry Arabidopsis seeds. It would be of interest to see whether dry seeds can be used for assessing thermotolerance.

Young seedlings, either dark- or light-grown, are the most frequently used developmental stages as they show more phenotypes than the simple germination phenotype observed in seeds. Viability of seedlings is the most popular phenotype for thermotolerance assays (Table 1). Viability is usually scored as the ability of the seedlings to generate new green leaves under permissive temperatures after a heat stress treatment. Hypocotyl and root elongation can be measured instead of the emergence of green leaves and have the advantage of being quantitative. Seedlings are grown in the dark before and after heat treatment to induce etiolation for hypocotyl elongation assays [28]. As with viability, this output trait can be used under the heat stress regimes for BT, SAT, and LAT. However, not all heat stress response mutants that show defect in viability are also defective in hypocotyl elongation (Table 1). For example, HSP1O1 and HSA32 KO mutants are severely defective in hypocotyl elongation [28, 30], but mutants of DGD1 [14], FTSH11 [32], TIL1 [41], $H S B P$ [42], and BOB1 (Kaplinsky and Perez, unpublished data) are not. In contrast the 
uvh3-1 mutant is defective in hypocotyl elongation but not in viability [13]. Using either one of these traits as the only phenotype for thermotolerance screening is not sufficient for identifying many important heat stress response genes.

Accumulation of chlorophyll in cotyledons following acclimation of heat stress challenged dark-grown seedlings and subsequent exposure to light is another useful phenotype for identification of genes with functions in thermotolerance [14, 27, 32]. The two thermotolerance-conferring proteins, DGD1 and FSTH11, identified by this method are localized in chloroplasts and are required for normal function of the organelle at high temperatures. In contrast, the loss-of-function mutant of HSP101, hot1-1, is not defective in chlorophyll accumulation after heat stress [14, 32]. These observations illustrate the importance of considering different plant needs for heat stress response genes functioning in different subcellular compartments.

Yellowing or bleaching of cotyledons or true leaves is a visible phenotype for light-grown seedlings, which can be quantified by measuring chlorophyll content, $\mathrm{Chl} \mathrm{a} / \mathrm{b}$ ratio, and the quantum yield of photosystem II (PSII; Table 1). Measurement of quantum yield of PSII is advantageous as this method is nondestructive and mutants identified using this approach can subsequently be used for other purposes including setting up crosses.

It is more challenging to use adult Arabidopsis plants for thermotolerance phenotyping than young seedlings. Unlike young seedlings that can be grown in large numbers in petri dishes, adult plants grown in pots are larger and growth chambers must usually be used for thermotolerance assays. Concerns about this type of heating device have been mentioned in previous sections. Nevertheless, some important genetic components of thermotolerance with distinct phenotypes in adult plants have been successfully revealed (Table 1). Detached organs, most often leaves, are alternative choices for thermotolerance phenotyping in mature plants and are easier to use than whole plants. Detached leaves or leaf discs incubated in a petri dish can be heated in a manner similar to seedling treatments. Several output traits can be measured on the detached leaves after heat stress treatment including chlorophyll content, electrolyte leakage, and electrochromic absorbance (see below).

Plant reproductive organs are far more sensitive to heat than other tissues [43, 44], and several studies on reproductive organ thermotolerance have been reported in Arabidopsis (Table 1). Unlike assays used for seeds and seedlings, which can be performed within one or two weeks of germination, assaying the heat tolerance of reproductive organs requires much longer periods of plant growth. While this can limit the scale of experiments, the reproductive stage of plant development is obviously relevant to plant productivity and is a major concern in agriculture, so studies of gene function at this stage are of great interest.

Some output traits of thermotolerance assays depend on the growth stage such as hypocotyl elongation in dark-grown seedlings. Other traits can be used at many different growth stages or in detached organs. For example, lipid peroxidation measured using thiobarbituric acidreactive substances assays and electrolyte leakage are frequently employed on seedlings as well as tissues collected from adult plants (Table 1). A triphenyltetrazolium chloride reduction assay has been used to measure root vitality and could presumably be used on other organs [45, 46]. The limitations of these methods have been discussed in [27]. Recently, three biophysical methods, circular dichroism (CD) spectrosocopy, electrochromic absorbance transients, and thermoluminescence, have been employed to assess the effect of isoprene on the thermal stability of thylakoid membranes in transgenic Arabidopsis [47]. Arabidopsis does not naturally emit isoprene and in this study transgenic Arabidopsis plants constitutively expressing an isoprene synthase gene from poplar produced isoprene and acquired enhanced tolerance to heat stress treatments. CD spectrosocopy determines 
structural changes in the thylakoid membranes. Flash-induced electrochromic absorbance change at $515 \mathrm{~nm}$ is used to monitor perturbation in ion permeability of membranes.

Thermoluminescence detects the structural alterations in both the donor and acceptor side of PSII (refer to [47] for details and references to these techniques). Viability and growth rate thermotolerance phenotypes under BT and TMHT heat stress regimes are in good agreement with the indexes determined by these biophysical measurements, suggesting that they may be of general use in heat stress phenotyping.

Different output traits are assayed after various periods of recovery following heat stress treatments (Fig. 1). Traits such as viability, lipid peroxidation, and hypocotyl elongation require several days for measurable phenotypes to develop. Other output traits such as photosynthetic efficiency and electrolyte leakage are commonly, but not always, assayed immediately after the heat treatment. For instance, some studies report cellular electrolyte leakage after 2-3 d of incubation at normal condition following heat stress treatment. This extended recovery time allows investigation of secondary effects of cell death as opposed to primary events. It should be noted that there is no linear relationship between early electrolyte leakage event and viability [41]. Lipid peroxidation levels are also not correlated well with the survival rate after heat stress treatment [48]. Because of this temporal complexity continuous monitoring of output traits during or after stress treatment may be needed in some cases as phenotypes might only be revealed within a short window of time [49].

\section{Phenotyping methods for studying heat stress response in crop plants}

By the end of this century growing season temperatures in the tropics and subtropics are predicted to exceed the hottest seasonal temperatures recorded in the last century [50]. As many crops will experience warmer environments, which are predicted to reduce productivity, climate change raises significant concerns about food security. Although it can be less convenient to study the genetic basis of heat stress tolerance in crop plants than in Arabidopsis the information gained from non-model systems has unique value as these studies can have direct implications for agriculture. Mechanisms of heat stress tolerance which exist in important crop species may not exist in Arabidopsis, for example the emission of isoprene mentioned above [51]. Increasing environmental temperatures often accompany other environmental stresses such as drought, high irradiance, and disease in field situations [52, 53]. Thus, appropriate phenotyping of responses to heat stress coupled with other stresses is important to the study of heat tolerance of crop plants. Although there are limitations when working in crop plants there is a large literature focused on heat stress response and thermotolerance in crop plants.

High temperatures constrain plant growth and can adversely affect seed germination, photosynthetic efficiency and other core metabolic processes, pollen viability, respiration, water relations, protein and membrane stability. Because of the wide range of effects that high temperatures have on plants many thermotolerance assays have been employed to assess the effects of a multitude of factors on heat stress tolerance of various plant species and in the identification of heat tolerant germplasms by plant breeders. For plant breeders an important objective is the development of an effective set of thermotolerance markers for marker assisted selection (MAS).

The three major parameters used in studies that compare thermotolerance levels in different crop cultivars, mutant versus wild type plants, and transgenic versus non-transgenic plant are summarized in Table 2. In the following sections we discuss these parameters. 


\subsection{Selection of heat stress regime and heating device}

BT, SAT, and TMHT but not LAT assays have been reported in studies using crop plant species (Table 2). For consistency we will use the same definitions of thermotolerance types described in Section 2.1.

There is only one report in crop plants detailing the characterization of a heat stress response gene genetic knockout: maize plants lacking HSP101 are defective in both BT and SAT [54]. Transgenic approaches have however been used extensively to assess the role of heat stress response genes in crop plant thermotolerance. One example is the constitutive expression of HSFA1A in tomato which enhances SAT in seedlings. Down-regulation of the same gene by co-suppression decreased the BT and SAT of seedlings and the TMHT of mature green fruit [55]. Other examples in which overexpression of single HSPs or metabolic enzymes enhanced one or multiple types of thermotolerance are summarized in Table 2.

Assays for BT, SAT, and TMHT have also been used to differentiate heat-tolerant and sensitive cultivars of lima bean, peanut, potato, rice, sunflower, and wheat. The genetic basis underlying heat-tolerant phenotypes in these species have yet to be identified. In general these kinds of studies do not investigate whether heat-tolerant lines have increases in multiple types of thermotolerance relative to heat-sensitive lines.

Although crop plants are larger than Arabidopsis, the heating devices used for crop plants are similar to those used in Arabidopsis research because many crop plant assays are conducted on seedlings or small portions of plants such as leaves or leaf punches. Thermotolerance studies on mature crop plants are either performed in large growth chambers or greenhouses.

\subsection{Selection of growth stage and output trait}

The temperature and duration of heat stress treatments resulting in changes in growth and development vary between plant tissues and growth stages. Seeds, seedlings, mature leaves, panicles or spikes, and fruits have all been used in crop thermotolerance studies (Table 2).

The germination of heat-treated seeds is commonly assayed by scoring radicle emergence for thermotolerance phenotyping of crop plants seeds. It has been used to measure both BT and TMHT (Table 2). Seed maturity and pre-treatments such as scarification, cold or warm stratification, and dry storage must be carefully considered prior to analyzing BT of seeds as changes in any of these may affect thermotolerance [56, 57]. As an example of the importance of these parameters, it has been suggested that seed traits including seed weight, volume, and density can be used to differentiate relative heat tolerance in cultivars of upland cotton $[57,58]$. Viability is the most commonly used phenotype in seedling studies, while growth rates determined by measuring fresh or dry weight and shoot and root length after heat stress treatment allows for quantitative measurements of thermotolerance.

Reproductive phases of plant development tend to be far more sensitive to heat stress than earlier stages [43]. Brief periods of heat stress can significantly suppress fertility in many species. Determining the thermotolerance of reproductive organs of cereal plants is of great interest as thermotolerance at this stage is directly related to grain filling and plant yield in heat stress conditions. Both anthesis and grain filling of many cereal crops grown in temperate regions are influenced by atmospheric temperature fluctuations [59]. Spikelet fertility and grain filling have been compared in heat-tolerant and -sensitive cultivars of rice and wheat, respectively, following exposure to prolonged moderate heat stress regimes (Table 2). The up-regulation of HSPs at high temperatures was identified in anthers of N22 rice, a heat-tolerant cultivar, suggesting that acquired thermotolerance is important in the 
reproductive stage of rice development [60]. Although we classified this type of acquired thermotolerance as TMHT due to continuous exposure to moderately high temperatures it remains to be seen whether TMHT and SAT are distinguishable in crop plants grown under field conditions.

Other assays including cellular membrane thermal stability, the level of heat treatment causing continuous membrane leakage, and triphenyltetrazolium chloride reduction by heattreated tissues as an index of cell viability [61-65] have also been used to assess thermotolerance in crop plants. Quantification of electrolyte leakage has been used to evaluate the genotypic contributions to high temperature responses in heat tolerant cultivars of both wheat and cotton [64, 66, 67]. Although the triphenyltetrazolium chloride reduction assay has been useful in several crop studies this approach is not commonly used in molecular genetic heat stress response studies. Chlorophyll accumulation has been used as an output of SAT for peanut and wheat leaves (Table 2). Finally, thermally-induced changes in photosynthetic parameters including maximum photochemical efficiency $(F V / F m)$ and $\mathrm{CO}_{2}$ assimilation have also been used to assess thermotolerance of heat stressed leaves (Table 2).

Recently, quantitative trait loci (QTL) mapping has been used to identify specific chromosome segments that contain candidate genes for heat tolerance [68-70]. The power of this approach to separate heat from other stresses is nicely illustrated in a recent wheat study which investigated the effects of drought and irrigation on yield. Over 100 QTLs influencing wheat yield under drought and heat stress were identified. Seventeen were associated with both stresses while 16 were exclusively associated with heat stress, demonstrating that this approach can be used to dissect complicated stress traits [71]. Even without determining the chromosomal locations of heat stress genes in crop plants, molecular genotyping technologies such as restriction fragment length polymorphisms (RFLPs), random amplification of polymorphic DNAs (RAPDs), amplified fragment length polymorphisms (AFLPs), microsatellites, and single-nucleotide polymorphisms (SNPs) have been used to estimate the genetic contributions underlying variation in crop plant heat tolerance $[67,70,72-74]$.

\section{Conclusions and Prospects}

Four distinct types of plant thermotolerance have been identified in Arabidopsis, suggesting that plants use diverse mechanisms in response to temperature changes in environment. We propose the term 'thermotolerance diversity' to describe these multiple mechanisms. Distinguishing between these types of thermotolerance is important for understanding how plants respond to heat stress. Recent work in Arabidopsis has described the functions of genes required for one or more than one type of thermotolerance (Table 1), and we expect this list to become longer as more researchers start to assay for all types of thermotolerance on a routine basis.

The same approaches should be used when assaying the effects of transgenes, as it is important to know whether they confer a specific type or a wide spectrum of thermotolerance and whether they cause defects in other types of thermotolerance. Similarly, multiple heat stress phenotypes need to be assayed when studying crop plants. The complete understanding of heat stress response generated by multiple types of thermotolerance data may provide important insights for enhancing overall thermotolerance in crop plants. It will be of great interest to see whether, with more detailed thermotolerance data, tailor-made thermotolerance types can be bred or engineered in crop plants in anticipation of future climate changes. 
Although we have only identified four major types of thermotolerance based on phenotyping studies, it is likely that each type can be further divided into different subtypes of thermotolerance over finer temperature ranges. For example, TMHT at $35-37^{\circ} \mathrm{C}$ may be conferred by a different set of genes than at $30-32^{\circ} \mathrm{C}$. Multiple mechanisms may exist for each kind of thermotolerance, and this may allow plants to fine tune their responses to high temperatures. Similar possibilities exist for other types of thermotolerance and a detailed description of thermotolerance diversity awaits elegantly designed phenotyping experiments. The effects of combination of heat stress and other stresses such as drought, high light levels, and UV are not discussed in this review. However, it is likely that heat stress response genes are involved in both thermotolerance as well as other stress responses [3, 9, 75-77]. Since plants are often challenged by multiple stresses in natural environments it will be necessary to perform thermotolerance phenotyping with multiple stresses to identify and understand these interactions. Likewise, multiple thermotolerance assays should be conducted to examine whether transgenes that enhance tolerance to environmental stresses such as drought and salt result in decreased thermotolerance.

Although Arabidopsis has many advantages for these kinds of studies, recent work in the unicellular algae Chlamydomonas reinhardtii [78] and the moss Physcomitrella patens [79] have demonstrated the power of these genetic systems for understanding evolutionarily conserved components in plant heat stress response. Because these organisms are more amenable for functional genomic studies [80-82] they should be instrumental in defining new paradigms in thermotolerance diversity.

Why and how stress proteins participate in different types of thermotolerance is only clear in a small number of cases. It is likely that the mode of action of a stress protein is essential for a subset of heat stress conditions. For example, HSP101, a molecular machine involved in protein disaggregation $[39,40,83]$ is required for tolerance to severe heat stresses but not for chronic heat stress at moderately high temperatures [15, 39]. Severe heat stress induces protein unfolding and aggregation while moderate temperatures probably do not. The use of in vivo assays for mis-folded proteins such as monitoring luciferase activity [40] allows ideas like this to be directly verified.

Some stress genes and their paralogs might have developed specialized roles for specific types of thermotolerance after genome duplication and subsequent subfunctionalization [9, $11,15,84]$. Recently we have begun to understand the differential roles of $H S F$ family genes in thermotolerance diversity. In Arabidopsis the master regulators of heat stress responses, the transcription factors HSFA1A/B/D in Arabidopsis, play major roles in four different types of thermotolerance [9]. HSFA1A in tomato plays the same dominant role in BT, SAT, and TMHT [55]. In contrast, HSFA2 amplifies and prolongs the heat stress response, thus affecting LAT more than SAT $[4,11,34,85]$. The functions of HSFA3 and HSFA7A have been reported for BT and SAT [86, 87]. Their roles in the other two types of thermotolerance remain to be examined. Intriguingly, HSFB1 and HSFB2B, two transcriptional repressors [88], were recently shown to exert opposite effects on BT and acquired thermotolerance. Double KO mutants of these genes have higher BT levels but lower levels of SAT and LAT than that of the wild type [89]. HSFA2, HSFA3, HSFA7A, HSFB1, and HSFB2B are down stream genes of HSFA1A/B/D [9, 10], indicating a complex regulatory network of heat stress response that confer differential protection to a wide range of heat stress regimes. Given the large number of genes implicated in heat stress responses and the complexity of these responses there is still much to be learned before we have a good understanding of how plant respond to high temperatures. Thermotolerance diversity is a new concept that should assist us in achieving this goal. 


\section{Acknowledgments}

We acknowledge support from Academia Sinica (grant AS-100-TP2-A02-4-2) and NSC (grants 97-2311B-001-007-MY3 and 100-2311-B-001-007) to YYC, from NIH (grant 1R15GM093933-01) to NJK, and NSC (grants 98-2324-B-008-002 and 99-2324-B-008-002-MY2) to CHY. We apologize to colleagues whose work we could not include because of space limitation. We also thank the six anonymous reviewers for constructive comments and suggestions.

\section{Abbreviations}

$\begin{array}{ll}\text { HSP } & \text { heat-shock protein } \\ \text { BT } & \text { basal thermotolerance } \\ \text { SAT } & \text { short-term acquired thermotolerance } \\ \text { LAT } & \text { long-term acquired thermotolerance } \\ \text { TMHT } & \text { thermotolerance to moderately high temperatures }\end{array}$

\section{References}

1. Wolkovich EM, Cook BI, Allen JM, Crimmins TM, Betancourt JL, Travers SE, Pau S, Regetz J, Davies TJ, Kraft NJB, Ault TR, Bolmgren K, Mazer SJ, McCabe GJ, McGill BJ, Parmesan C, Salamin N, Schwartz MD, Cleland EE. Warming experiments underpredict plant phenological responses to climate change. Nature advance online publication. 2012

2. Busch W, Wunderlich M, Schöffl F. Identification of novel heat shock factor-dependent genes and biochemical pathways in Arabidopsis thaliana. Plant J. 2005; 41:1-14. [PubMed: 15610345]

3. Rizhsky L, Liang H, Shuman J, Shulaev V, Davletova S, Mittler R. When defense pathways collide. The response of Arabidopsis to a combination of drought and heat stress. Plant Physiol. 2004; 134:1683-1696. [PubMed: 15047901]

4. Schramm F, Ganguli A, Kiehlmann E, Englich G, Walch D, von Koskull-Doring P. The heat stress transcription factor HsfA2 serves as a regulatory amplifier of a subset of genes in the heat stress response in Arabidopsis. Plant Mol. Biol. 2006; 60:759-772. [PubMed: 16649111]

5. Swindell W, Huebner M, Weber A. Transcriptional profiling of Arabidopsis heat shock proteins and transcription factors reveals extensive overlap between heat and non-heat stress response pathways. BMC Genomics. 2007; 8:125. [PubMed: 17519032]

6. Hu W, Hu G, Han B. Genome-wide survey and expression profiling of heat shock proteins and heat shock factors revealed overlapped and stress specific response under abiotic stresses in rice. Plant Sci. 2009; 176:583-590.

7. Ginzberg I, Barel G, Ophir R, Tzin E, Tanami Z, Muddarangappa T, de Jong W, Fogelman E. Transcriptomic profiling of heat-stress response in potato periderm. J. Exp. Bot. 2009; 60:44114421. [PubMed: 19752048]

8. Endo M, Tsuchiya T, Hamada K, Kawamura S, Yano K, Ohshima M, Higashitani A, Watanabe M, Kawagishi-Kobayashi M. High temperatures cause male sterility in rice plants with transcriptional alterations during pollen development. Plant Cell Physiol. 2009; 50:1911-1922. [PubMed: 19808807]

9. Liu HC, Liao HT, Charng YY. The role of class A1 heat shock factors (HSFA1s) in response to heat and other stresses in Arabidopsis. Plant Cell Environ. 2011; 34:738-751. [PubMed: 21241330]

10. Yoshida T, Ohama N, Nakajima J, Kidokoro S, Mizoi J, Nakashima K, Maruyama K, Kim JM, Seki M, Todaka D, Osakabe Y, Sakuma Y, Schöffl F, Shinozaki K, Yamaguchi-Shinozaki K. Arabidopsis HsfA1 transcription factors function as the main positive regulators in heat shockresponsive gene expression. Mol. Genet. Genomics. 2011; 286:321-332. [PubMed: 21931939]

11. Charng YY, Liu HC, Liu NY, Chi WT, Wang CN, Chang SH, Wang TT. A heat-inducible transcription factor, HsfA2, is required for extension of acquired thermotolerance in Arabidopsis. Plant Physiol. 2007; 143:251-262. [PubMed: 17085506] 
12. Sharkey, T.; Schrader, S. High temperature stress. In: Madhava Rao, KV.; Raghavendra, AS.; Janardhan Reddy, K., editors. Physiology and Molecular Biology of Stress Tolerance in Plants. Netherlands: Springer; 2006. p. 101-129.

13. Larkindale J, Hall JD, Knight MR, Vierling E. Heat stress phenotypes of Arabidopsis mutants implicate multiple signaling pathways in the acquisition of thermotolerance. Plant Physiol. 2005; 138:882-897. [PubMed: 15923322]

14. Chen J, Burke JJ, Xin Z, Xu C, Velten J. Characterization of the Arabidopsis thermosensitive mutant attsO2 reveals an important role for galactolipids in thermotolerance. Plant Cell Environ. 2006; 29:1437-1448. [PubMed: 17080965]

15. Hu C, Lin SY, Chi WT, Charng YY. Recent gene duplication and subfunctionalization produced a mitochondrial GrpE, the nucleotide exchange factor of Hsp70 complex, specialized in thermotolerance to chronic heat stress in Arabidopsis. Plant Physiol. 2012; 158:747-758. [PubMed: 22128139]

16. Wu SJ, Wang LC, Yeh CH, Lu CA, Wu SJ. Isolation and characterization of the Arabidopsis heatintolerant 2 (hit2) mutant reveal the essential role of the nuclear export receptor EXPORTIN1A (XPO1A) in plant heat tolerance. New Phytol. 2010; 186:833-842. [PubMed: 20345641]

17. Wahid A, Gelani S, Ashraf M, Foolad MR. Heat tolerance in plants: An overview. Environ. Exp. Bot. 2007; 61:199-223.

18. Kotak S, Larkindale J, Lee U, von Koskull-Doring P, Vierling E, Scharf KD. Complexity of the heat stress response in plants. Curr. Opin. Plant Biol. 2007; 10:310-316. [PubMed: 17482504]

19. von Koskull-Döring P, Scharf KD, Nover L. The diversity of plant heat stress transcription factors. Trends Plant Sci. 2007; 12:452-457. [PubMed: 17826296]

20. Hua J. From freezing to scorching, transcriptional responses to temperature variations in plants. Curr. Opin. Plant Biol. 2009; 12:568-573. [PubMed: 19716335]

21. Saidi Y, Finka A, Goloubinoff P. Heat perception and signalling in plants: a tortuous path to thermotolerance. New Phytol. 2011; 190:556-565. [PubMed: 21138439]

22. Chauhan H, Khurana N, Agarwal P, Khurana P. Heat shock factors in rice (Oryza sativa): genomewide expression analysis during reproductive development and abiotic stress. Mol. Genet. Genomics. 2011; 286:171-187. [PubMed: 21792744]

23. Scharf K-D, Berberich T, Ebersberger I, Nover L. The plant heat stress transcription factor (Hsf) family: Structure, function and evolution. Biochim. Biophys. Acta Gene Regul. Mech. 2012; 1819:104-119.

24. Mittler R, Finka A, Goloubinoff P. How do plants feel the heat? Trends Biochem. Sci. 2012; 37:118-125. [PubMed: 22236506]

25. Koornneef M, Meinke D. The development of Arabidopsis as a model plant. Plant J. 2010; 61:909-921. [PubMed: 20409266]

26. Lee JH, Hubel A, Schöffl F. Derepression of the activity of genetically engineered heat shock factor causes constitutive synthesis of heat shock proteins and increased thermotolerance in transgenic Arabidopsis. Plant J. 1995; 8:603-612. [PubMed: 7496404]

27. Burke JJ, O'Mahony PJ, Oliver MJ. Isolation of Arabidopsis mutants lacking components of acquired thermotolerance. Plant Physiol. 2000; 123:575-587. [PubMed: 10859187]

28. Hong SW, Vierling E. Mutants of Arabidopsis thaliana defective in the acquisition of tolerance to high temperature stress. Proc. Natl. Acad. Sci. USA. 2000; 97:4392-4397. [PubMed: 10760305]

29. Wu SJ, Locy RD, Shaw JJ, Cherry JH, Singh NK. Mutation in Arabidopsis HIT1 locus causing heat and osmotic hypersensitivity. J. Plant Physiol. 2000; 157:543-547.

30. Charng YY, Liu HC, Liu NY, Hsu FC, Ko SS. Arabidopsis Hsa32, a novel heat-shock protein, is essential for acquired thermotolerance during a long recovery period after acclimation treatment. Plant Physiol. 2006; 140:1297-1305. [PubMed: 16500991]

31. Larkindale J, Vierling E. Core genome responses involved in acclimation to high temperature. Plant Physiol. 2008; 146:748-761. [PubMed: 18055584]

32. Chen J, Burke JJ, Velten J, Xin Z. FtsH11 protease plays a critical role in Arabidopsis thermotolerance. Plant J. 2006; 48:73-84. [PubMed: 16972866] 
33. Clarke SM, Cristescu SM, Miersch O, Harren FJM, Wasternack C, Mur LAJ. Jasmonates act with salicylic acid to confer basal thermotolerance in Arabidopsis thaliana. New Phytol. 2009; 182:175-187. [PubMed: 19140948]

34. Meiri D, Breiman A. Arabidopsis ROF1 (FKBP62) modulates thermotolerance by interacting with HSP90.1 and affecting the accumulation of HsfA2-regulated sHSPs. Plant J. 2009; 59:387-399. [PubMed: 19366428]

35. Meiri D, Tazat K, Cohen-Peer R, Farchi-Pisanty O, Aviezer-Hagai K, Avni A, Breiman A. Involvement of Arabidopsis ROF2 (FKBP65) in thermotolerance. Plant Mol. Biol. 2010; 72:191203. [PubMed: 19876748]

36. Liu NY, Ko SS, Yeh KC, Charng YY. Isolation and characterization of tomato Hsa32 encoding a novel heat-shock protein. Plant Sci. 2006; 170:976-985.

37. Zhang JX, Wang C, Yang CY, Wang JY, Chen L, Bao XM, Zhao YX, Zhang H, Liu J. The role of arabidopsis AtFes1A in cytosolic Hsp70 stability and abiotic stress tolerance. Plant J. 2010; 62:539-548. [PubMed: 20536787]

38. Boyes DC, Zayed AM, Ascenzi R, McCaskill AJ, Hoffman NE, Davis KR, Gorlach J. Growth stage-based phenotypic analysis of Arabidopsis : a model for high throughput functional genomics in plants. Plant Cell. 2001; 13:1499-1510. [PubMed: 11449047]

39. Queitsch C, Hong SW, Vierling E, Lindquist S. Heat shock protein 101 plays a crucial role in thermotolerance in Arabidopsis. Plant Cell. 2000; 12:479-492. [PubMed: 10760238]

40. Hong SW, Lee U, Vierling E. Arabidopsis hot mutants define multiple functions required for acclimation to high temperatures. Plant Physiol. 2003; 132:757-767. [PubMed: 12805605]

41. Chi WT, Fung RWM, Liu HC, Hsu CC, Charng YY. Temperature-induced lipocalin is required for basal and acquired thermotolerance in Arabidopsis. Plant Cell and Environment. 2009; 32:917927.

42. Hsu SF, Lai HC, Jinn TL. Cytosolic-localized heat shock factor binding protein, AtHSBP, functions as a negative regulator of heat shock response by translocation to the nucleus and is required for seed development in Arabidopsis. Plant Physiol. 2010; 153:773-784. [PubMed: 20388662]

43. Hall AE. Breeding for heat tolerance. Plant Breed Rev. 1992; 10:129-168.

44. Sakata T, Oshino T, Miura S, Tomabechi M, Tsunaga Y, Higashitani N, Miyazawa Y, Takahashi H, Watanabe M, Higashitani A. Auxins reverse plant male sterility caused by high temperatures. Proc. Natl. Acad. Sci. USA. 2010; 107:8569-8574. [PubMed: 20421476]

45. Jinn T-L, Chiu C-C, Song W-W, Chen Y-M, Lin C-Y. Azetidine-induced Accumulation of Class I Small Heat Shock Proteins in the Soluble Fraction Provides Thermotolerance in Soybean Seedlings. Plant Cell Physiol. 2004; 45:1759-1767. [PubMed: 15557296]

46. Zhou W, Zhou T, Li MX, Zhao CL, Jia N, Wang XX, Sun YZ, Li GL, Xu M, Zhou RG, Li B. The Arabidopsis J-protein AtDjB1 facilitates thermotolerance by protecting cells against heat-induced oxidative damage. New Phytol. 2012; 194:364-378. [PubMed: 22356282]

47. Velikova V, Varkonyi Z, Szabo M, Maslenkova L, Nogues I, Kovacs L, Peeva V, Busheva M, Garab G, Sharkey TD, Loreto F. Increased thermostability of thylakoid membranes in isopreneemitting leaves probed with three biophysical techniques. Plant Physiol. 2011; 157:905-916. [PubMed: 21807886]

48. Wang LC, Tsai MC, Chang KY, Fan YS, Yeh CH, Wu SJ. Involvement of the Arabidopsis HIT1/ AtVPS53 tethering protein homologue in the acclimation of the plasma membrane to heat stress. J. Exp. Bot. 2011; 62:3609-3620. [PubMed: 21398432]

49. Loivamäki M, Gilmer F, Fischbach RJ, Sörgel C, Bachl A, Walter A, Schnitzler J-P. Arabidopsis, a model to study biological functions of isoprene emission? Plant Physiol. 2007; 144:1066-1078. [PubMed: 17468218]

50. Battisti DS, Naylor RL. Historical warnings of future food insecurity with unprecedented seasonal heat. Science. 2009; 323:240-244. [PubMed: 19131626]

51. Sharkey TD, Wiberley AE, Donohue AR. Isoprene emission from plants: why and how. Ann. Bot. 2008; 101:5-18. [PubMed: 17921528] 
52. Hüve K, Bichele I, Rasulov B, Niinemets Ü. When it is too hot for photosynthesis: heat-induced instability of photosynthesis in relation to respiratory burst, cell permeability changes and $\mathrm{H}_{2} \mathrm{O}_{2}$ formation. Plant, Cell \& Environment. 2011; 34:113-126.

53. Webb KM, Oña I, Bai J, Garrett KA, Mew T, Vera Cruz CM, Leach JE. A benefit of high temperature: increased effectiveness of a rice bacterial blight disease resistance gene. New Phytol. 2010; 185:568-576. [PubMed: 19878463]

54. Nieto-Sotelo J, Martinez LM, Ponce G, Cassab GI, Alagon A, Meeley RB, Ribaut J-M, Yang R. Maize HSP101 plays important roles in both induced and basal thermotolerance and primary root growth. Plant Cell. 2002; 14:1621-1633. [PubMed: 12119379]

55. Mishra SK, Tripp J, Winkelhaus S, Tschiersch B, Theres K, Nover L, Scharf KD. In the complex family of heat stress transcription factors, HsfA1 has a unique role as master regulator of thermotolerance in tomato. Genes Dev. 2002; 16:1555-1567. [PubMed: 12080093]

56. Seepaul R, Macoon B, Reddy KR, Baldwin B. Switchgrass (Panicum virgatum L.) intraspecific variation and thermotolerance classification using in vitro seed germination assay. Am. J. Plant Sci. 2011; 2:134-147.

57. ur Rahman H, Malik SA, Saleem M, Hussain F. Evaluation of seed physical traits in relation to heat tolerance in upland cotton. Pak. J. Bot. 2007; 39:475-483.

58. Rehman H, Rehman A, Khan WS, Murtaza N. Genotype-environment interaction and stability of seed quality traits in Gossypium hirsutum L. cultivars. Pak. Cottons. 1993; 37:21-27.

59. Zakaria S, Matsuda T, Tajima S, Niita Y. Effect of high temperature at ripening stage on the reserve accumulation in seed in some rice cultivars. Plant Prod. Sci. 2002; 5:160-168.

60. Jagadish SVK, Muthurajan R, Oane R, Wheeler TR, Heuer S, Bennett J, Craufurd PQ. Physiological and proteomic approaches to address heat tolerance during anthesis in rice (Oryza sativa L.). J. Exp. Bot. 2010; 61:143-156. [PubMed: 19858118]

61. Krishnan M, Nguyen HT, Burke JJ. Heat shock protein synthesis and thermal tolerance in wheat. Plant Physiol. 1989; 90:140-145. [PubMed: 16666724]

62. Kuo HF, Tsai YF, Young LS, Lin CY. Ethanol treatment triggers a heat shock-like response but no thermotolerance in soybean (Glycine max cv. Kaohsiung No.8) seedlings. Plant Cell Environ. 2000; 23:1099-1108.

63. Ibrahim AMH, Quick JS. Heritability of heat tolerance in winter and spring wheat. Crop Sci. 2001; 41:1401-1405.

64. ur Rahman H, Malik SA, Saleem M. Heat tolerance of upland cotton during the fruiting stage evaluated using cellular membrane thermostability. Field Crops Res. 2004; 85:149-158.

65. Yeh C-H, Wu S-J, Tsai Y-F, Chen H-Y, Lin C-Y. Physiological effects of azetidine on cellular leakage in soybean seedlings. Plant Sci. 2007; 172:1124-1130.

66. Saadalla MM, Quick JS, Shanahan JF. Heat tolerance in winter wheat: II. membrane thermostability and field performance. Crop Sci. 1990; 30:1248-1251.

67. Rana RM, Khan SH, Ali Z, Khan AI, Khan IA. Elucidation of thermotolerance diversity in cotton (Gossypium hirsutum L.) using physio-molecular approaches. Genetics and molecular research : GMR. 2011; 10:1156-1167. [PubMed: 21710467]

68. Mohammadi V, Zali AA, Bihamta MR. Mapping QTLs for heat tolerance in wheat. J. Agric. Sci. Technol. 2008; 10:261-267.

69. Yang J, Sears RG, Gill BS, Paulsen GM. Quantitative and molecular characterization of heat tolerance in hexaploid wheat. Euphytica. 2002; 126:275-282.

70. Ye C, Argayoso MA, Redoña ED, Sierra SN, Laza MA, Dilla CJ, Mo Y, Thomson MJ, Chin J, Delaviña CB, Diaz GQ, Hernandez JE. Mapping QTL for heat tolerance at flowering stage in rice using SNP markers. Plant Breeding. 2012; 131:33-41.

71. Pinto RS, Reynolds MP, Mathews KL, McIntyre CL, Olivares-Villegas JJ, Chapman SC. Heat and drought adaptive QTL in a wheat population designed to minimize confounding agronomic effects. Theor. Appl. Genet. 2010; 121:1001-1021. [PubMed: 20523964]

72. Barakat MN, Al-Doss AA, Elshafei AA, Moustafa KA. Identification of new microsatellite marker linked to the grain filling rate as indicator for heat tolerance genes in F2 wheat population. Australian J. Crop Sci. 2011; 5:104-110. 
73. Demeke T, Lynch DR, Kawchuk LM, Kozub GC, Armstrong JD. Genetic diversity of potato determined by random amplified polymorphic DNA analysis. Plant Cell Rep. 1996; 15:662-667.

74. Gepts P. The use of molecular and biochemical markers in crop evolution studies. Evol. Biol. 1993; 27:51-94.

75. Yamanouchi U, Yano M, Lin H, Ashikari M, Yamada K. A rice spotted leaf gene, Spl7, encodes a heat stress transcription factor protein. Proc. Natl. Acad. Sci. USA. 2002; 99:7530-7535. [PubMed: 12032317]

76. Nishizawa A, Yabuta Y, Yoshida E, Maruta T, Yoshimura K, Shigeoka S. Arabidopsis heat shock transcription factor A2 as a key regulator in response to several types of environmental stress. Plant J. 2006; 48:535-547. [PubMed: 17059409]

77. Wu X, Shiroto Y, Kishitani S, Ito Y, Toriyama K. Enhanced heat and drought tolerance in transgenic rice seedlings overexpressing OSWRKY11 under the control of HSP101 promoter. Plant Cell Rep. 2009; 28:21-30. [PubMed: 18818929]

78. Strenkert D, Schmollinger S, Sommer F, Schulz-Raffelt M, Schroda M. Transcription factordependent chromatin remodeling at heat shock and copper-responsive promoters in Chlamydomonas reinhardtii. Plant Cell. 2011; 23:2285-2301. [PubMed: 21705643]

79. Saidi Y, Finka A, Muriset M, Bromberg Z, Weiss YG, Maathuis FJM, Goloubinoff P. The heat shock response in moss plants is regulated by specific calcium-permeable channels in the plasma membrane. Plant Cell. 2009; 21:2829-2843. [PubMed: 19773386]

80. Grossman AR, Harris EE, Hauser C, Lefebvre PA, Martinez D, Rokhsar D, Shrager J, Silflow CD, Stern D, Vallon O, Zhang Z. Chlamydomonas reinhardtii at the crossroads of genomics. Eukaryot. Cell. 2003; 2:1137-1150. [PubMed: 14665449]

81. Reski R, Frank W. Moss (Physcomitrella patens) functional genomics - Gene discovery and tool development, with implications for crop plants and human health. Brief. Funct. Genomic. Proteomic. 2005; 4:48-57. [PubMed: 15975264]

82. Cove D. The moss Physcomitrella patens. Annu. Rev. Genet. 2005; 39:339-358. [PubMed: 16285864]

83. Agarwal M, Sahi C, Katiyar-Agarwal S, Agarwal S, Young T, Gallie DR, Sharma VM, Ganesan K, Grover A. Molecular characterization of rice hsp101: complementation of yeast hsp104 mutation by disaggregation of protein granules and differential expression in indica and japonica rice types. Plant Mol. Biol. 2003; 51:543-553. [PubMed: 12650620]

84. Dafny-Yelin M, Tzfira T, Vainstein A, Adam Z. Non-redundant functions of sHSP-CIs in acquired thermotolerance and their role in early seed development in Arabidopsis. Plant Mol. Biol. 2008; 67:363-373. [PubMed: 18379884]

85. Li C, Chen Q, Gao X, Qi B, Chen N, Xu S, Chen J, Wang X. AtHsfA2 modulates expression of stress responsive genes and enhances tolerance to heat and oxidative stress in Arabidopsis. Sci. China. C. Life Sci. 2005; 48:540-550. [PubMed: 16483133]

86. Schramm F, Larkindale J, Kiehlmann E, Ganguli A, Englich G, Vierling E, von Koskull-Doring P. A cascade of transcription factor DREB2A and heat stress transcription factor HsfA3 regulates the heat stress response of Arabidopsis. Plant J. 2008; 53:264-274. [PubMed: 17999647]

87. Yoshida T, Sakuma Y, Todaka D, Maruyama K, Qin F, Mizoi J, Kidokoro S, Fujita Y, Shinozaki K, Yamaguchi-Shinozaki K. Functional analysis of an Arabidopsis heat-shock transcription factor HsfA3 in the transcriptional cascade downstream of the DREB2A stress-regulatory system. Biochem. Biophys. Res. Commun. 2008; 368:515-521. [PubMed: 18261981]

88. Ikeda M, Ohme-Takagi M. A novel group of transcriptional repressors in Arabidopsis. Plant Cell Physiol. 2009; 50:970-975. [PubMed: 19324928]

89. Ikeda M, Mitsuda N, Ohme-Takagi M. Arabidopsis HsfB1 and HsfB2b act as repressors for the expression of heat-inducible Hsfs but positively regulate the acquired thermotolerance. Plant Physiol. 2011; 157:1243-1254. [PubMed: 21908690]

90. Dong H, Zhen Z, Peng J, Chang L, Gong Q, Wang NN. Loss of ACS7 confers abiotic stress tolerance by modulating ABA sensitivity and accumulation in Arabidopsis. J. Exp. Bot. 2011; 62:4875-4887. [PubMed: 21765163] 
91. Li GL, Chang H, Li B, Zhou W, Sun DY, Zhou RG. The roles of the atDjA2 and atDjA3 molecular chaperone proteins in improving thermotolerance of Arabidopsis thaliana seedlings. Plant Sci. 2007; 173:408-416.

92. Watanabe N, Lam E. Arabidopsis Bax inhibitor-1 functions as an attenuator of biotic and abiotic types of cell death. Plant J. 2006; 45:884-894. [PubMed: 16507080]

93. Perez DE, Hoyer JS, Johnson AI, Moody ZR, Lopez J, Kaplinsky NJ. BOBBER1 is a noncanonical Arabidopsis small heat shock protein required for both development and thermotolerance. Plant Physiol. 2009; 151:241-252. [PubMed: 19571304]

94. Gao H, Brandizzi F, Benning C, Larkin RM. A membrane-tethered transcription factor defines a branch of the heat stress response in Arabidopsis thaliana. Proc. Natl. Acad. Sci. USA. 2008; 105:16398-16403. [PubMed: 18849477]

95. Zhang W, Zhou RG, Gao YJ, Zheng SZ, Xu P, Zhang SQ, Sun DY. Molecular and genetic evidence for the key role of AtCaM3 in heat-shock signal transduction in Arabidopsis thaliana. Plant Physiol. 2009; 149:1773-1784. [PubMed: 19211698]

96. Yan J, Wang J, Li Q, Hwang JR, Patterson C, Zhang H. AtCHIP, a U-Box-containing E3 ubiquitin ligase, plays a critical role in temperature stress tolerance in Arabidopsis. Plant Physiol. 2003; 132:861-869. [PubMed: 12805616]

97. Su PH, Li HM. Arabidopsis stromal 70-kD heat shock proteins are essential for plant development and important for thermotolerance of germinating seeds. Plant Physiol. 2008; 146:1231-1241. [PubMed: 18192441]

98. Kwon Y, Kim SH, Jung MS, Kim MS, Oh JE, Ju HW, Kim KI, Vierling E, Lee H, Hong SW. Arabidopsis hot 2 encodes an endochitinase-like protein that is essential for tolerance to heat, salt and drought stresses. Plant J. 2007; 49:184-193. [PubMed: 17156413]

99. Sakuma Y, Maruyama K, Qin F, Osakabe Y, Shinozaki K, Yamaguchi-Shinozaki K. Dual function of an Arabidopsis transcription factor DREB2A in water-stress-responsive and heat-stressresponsive gene expression. Proc. Natl. Acad. Sci. USA. 2006; 103:18822-18827. [PubMed: 17030801]

100. Lim CJ, Hwang JE, Chen H, Hong JK, Yang KA, Choi MS, Lee KO, Chung WS, Lee SY, Lim CO. Over-expression of the Arabidopsis DRE/CRT-binding transcription factor DREB2C enhances thermotolerance. Biochem. Biophys. Res. Commun. 2007; 362:431-436. [PubMed: 17716623]

101. Routaboul JM, Skidmore C, Wallis JG, Browse J. Arabidopsis mutants reveal that short- and long-term thermotolerance have different requirements for trienoic fatty acids. J. Exp. Bot. 2012; 63:1435-1443. [PubMed: 22140238]

102. Murakami Y, Tsuyama M, Kobayashi Y, Kodama H, Iba K. Trienoic fatty acids and plant tolerance of high temperature. Science. 2000; 287:476-479. [PubMed: 10642547]

103. Zhang S, Wang X. Overexpression of GASA5 increases the sensitivity of Arabidopsis to heat stress. J. Plant Physiol. 2011; 168:2093-2101. [PubMed: 21835493]

104. Lee U, Wie C, Fernandez BO, Feelisch M, Vierling E. Modulation of nitrosative stress by Snitrosoglutathione reductase is critical for thermotolerance and plant growth in Arabidopsis. Plant Cell. 2008; 20:786-802. [PubMed: 18326829]

105. Prändl R, Hinderhofer K, Eggers-Schumacher G, Schöffl F. HSF3, a new heat shock factor from Arabidopsis thaliana, derepresses the heat shock response and confers thermotolerance when overexpressed in transgenic plants. Mol. Gen. Genet. 1998; 258:269-278. [PubMed: 9645433]

106. Ogawa D, Yamaguchi K, Nishiuchi T. High-level overexpression of the Arabidopsis HsfA2 gene confers not only increased themotolerance but also salt/osmotic stress tolerance and enhanced callus growth. J. Exp. Bot. 2007; 58:3373-3383. [PubMed: 17890230]

107. Lee JH, Schöffl F. An Hsp70 antisense gene affects the expression of HSP70/HSC70, the regulation of HSF, and the acquisition of thermotolerance in transgenic Arabidopsis thaliana. Mol. Gen. Genet. 1996; 252:11-19. [PubMed: 8804399]

108. Sasaki K, Saito T, Lämsä M, Oksman-Caldentey K-M, Suzuki M, Ohyama K, Muranaka T, Ohara K, Yazaki K. Plants utilize isoprene emission as a thermotolerance mechanism. Plant Cell Physiol. 2007; 48:1254-1262. [PubMed: 17711876] 
109. Suzuki N, Bajad S, Shuman J, Shulaev V, Mittler R. The transcriptional co-activator MBF1C is a key regulator of thermotolerance in Arabidopsis thaliana. J. Biol. Chem. 2008; 283:9269-9275. [PubMed: 18201973]

110. Shedge V, Davila J, Arrieta-Montiel MP, Mohammed S, Mackenzie SA. Extensive rearrangement of the Arabidopsis mitochondrial genome elicits cellular conditions for thermo-tolerance. Plant Physiol. 2010; 152:1960-1970. [PubMed: 20139171]

111. Xuan Y, Zhou S, Wang L, Cheng Y, Zhao L. Nitric oxide functions as a signal and acts upstream of AtCaM3 in thermotolerance in Arabidopsis seedlings. Plant Physiol. 2010; 153:1895-1906. [PubMed: 20576787]

112. Lv W, Lin B, Zhang M, Hua X. Proline accumulation is inhibitory to Arabidopsis seedlings during heat stress. Plant Physiol. 2011

113. Zheng SZ, Liu YL, Li B, Shang ZL, Zhou RG, Sun DY. Phosphoinositide-specific phospholipase C9 is involved in the thermotolerance of Arabidopsis. Plant J. 2012; 69:689-700. [PubMed: 22007900]

114. Park JH, Lee SY, Kim WY, Jung YJ, Chae HB, Jung HS, Kang CH, Shin MR, Kim SY, Su'udi M, Yun DJ, Lee KO, Kim MG, Lee SY. Heat-induced chaperone activity of serine/threonine protein phosphatase 5 enhances thermotolerance in Arabidopsis thaliana. New Phytol. 2011; 191:692-705. [PubMed: 21564098]

115. Liu HT, Li G-L, Chang HUI, Sun DY, Zhou RG, Li B. Calmodulin-binding protein phosphatase PP7 is involved in thermotolerance in Arabidopsis. Plant Cell Environ. 2007; 30:156-164. [PubMed: 17238907]

116. Kurek I, Chang TK, Bertain SM, Madrigal A, Liu L, Lassner MW, Zhu G. Enhanced thermostability of Arabidopsis Rubisco activase improves photosynthesis and growth rates under moderate heat stress. Plant Cell. 2007; 19:3230-3241. [PubMed: 17933901]

117. Wang S, Kurepa J, Smalle JA. The Arabidopsis 26S proteasome subunit RPN1a is required for optimal plant growth and stress responses. Plant Cell Physiol. 2009; 50:1721-1725. [PubMed: 19605416]

118. Yu H-D, Yang X-F, Chen S-T, Wang Y-T, Li J-K, Shen Q, Liu X-L, Guo F-Q. Downregulation of chloroplast RPS1 negatively modulates nuclear heat-responsive expression of HsfA2 and Its target genes in Arabidopsis. PLoS Genet. 2012; 8 e1002669.

119. Yabuta Y, Nishizawa-Yokoi A, Ono K, Shigeoka S. Arabidopsis Sgt1a as an important factor for the acquirement of thermotolerance. Plant Sci. 2009; 177:676-681.

120. Yoo CY, Miura K, Jin JB, Lee J, Park HC, Salt DE, Yun DJ, Bressan RA, Hasegawa PM. SIZ1 small ubiquitin-like modifier E3 ligase facilitates basal thermotolerance in Arabidopsis independent of salicylic acid. Plant Physiol. 2006; 142:1548-1558. [PubMed: 17041025]

121. Cohen-Peer R, Schuster S, Meiri D, Breiman A, Avni A. Sumoylation of Arabidopsis heat shock factor A2 (HsfA2) modifies its activity during acquired thermotholerance. Plant Mol. Biol. 2010; 74:33-45. [PubMed: 20521085]

122. Miller G, Suzuki N, Rizhsky L, Hegie A, Koussevitzky S, Mittler R. Double mutants deficient in cytosolic and thylakoid ascorbate peroxidase reveal a complex mode of interaction between reactive oxygen species, plant development, and response to abiotic stresses. Plant Physiol. 2007; 144:1777-1785. [PubMed: 17556505]

123. Yang KZ, Xia C, Liu XL, Dou XY, Wang W, Chen LQ, Zhang XQ, Xie LF, He L, Ma X, Ye D. A mutation in THERMOSENSITIVE MALE STERILE 1, encoding a heat shock protein with DnaJ and PDI domains, leads to thermosensitive gametophytic male sterility in Arabidopsis. Plant J. 2009; 57:870-882. [PubMed: 18980646]

124. Lee C-F, Pu H-Y, Wang L-C, Sayler R, Yeh C-H, Wu S-J. Mutation in a homolog of yeast Vps53p accounts for the heat and osmotic hypersensitive phenotypes in Arabidopsis hit1-1 mutant. Planta. 2006; 224:330-338. [PubMed: 16408208]

125. Li S, Fu Q, Chen L, Huang W, Yu D. Arabidopsis thaliana WRKY25, WRKY26, and WRKY33 coordinate induction of plant thermotolerance. Planta. 2011; 233:1237-1252. [PubMed: 21336597] 
126. Malik MK, Slovin JP, Hwang CH, Zimmerman JL. Modified expression of a carrot small heat shock protein gene, Hsp17.7, results in increased or decreased thermotolerance. Plant J. 1999; 20:89-99. [PubMed: 10571868]

127. Hong B, Ma C, Yang Y, Wang T, Yamaguchi-Shinozaki K, Gao J. Over-expression of AtDREB1A in chrysanthemum enhances tolerance to heat stress. Plant Mol. Biol. 2009; 70:231240. [PubMed: 19234675]

128. ur Rahman H. Environmental interaction, additive and non-additive genetic variability is involved in the expression of tissue and whole-plant heat tolerance in upland cotton (Gossypium hirsutum. L). Genet. Mol. Biol. 2006; 29:525-532.

129. Xing J, Xu Y, Tian J, Gianfagna T, Huang B. Suppression of shade- or heat-induced leaf senescence in creeping bentgrass through transformation with the ipt gene for cytokinin synthesis. J. Am. Soc. Hort. Sci. 2009; 134:602-609.

130. Xu Y, Tian J, Gianfagna T, Huang B. Effects of SAG12-ipt expression on cytokinin production, growth and senescence of creeping bentgrass (Agrostis stolonifera L.) under heat stress. Plant Growth Regul. 2009; 57:281-291.

131. Keeler SJ, Boettger CM, Haynes JG, Kuches KA, Johnson MM, Thureen DL, Keeler CL Jr, Kitto SL. Acquired thermotolerance and expression of the HSP100/ClpB genes of lima bean. Plant Physiol. 2000; 123:1121-1132. [PubMed: 10889261]

132. Selvaraj M, Burow G, Burke J, Belamkar V, Puppala N, Burow M. Heat stress screening of peanut (Arachis hypogaea L.) seedlings for acquired thermotolerance. Plant Growth Regul. 2011; 65:83-91.

133. Ahn Y-J, Claussen K, Zimmerman JL. Genotypic differences in the heat-shock response and thermotolerance in four potato cultivars. Plant Sci. 2004; 166:901-911.

134. Katiyar-Agarwal S, Agarwal M, Grover A. Heat-tolerant basmati rice engineered by overexpression of hsp101. Plant Mol. Biol. 2003; 51:677-686. [PubMed: 12678556]

135. Murakami T, Matsuba S, Funatsuki H, Kawaguchi K, Saruyama H, Tanida M, Sato Y. Overexpression of a small heat shock protein, sHSP17.7, confers both heat tolerance and UV-B resistance to rice plants. Mol. Breeding. 2004; 13:165-175.

136. Feng LL, Wang K, Li Y, Tan YP, Kong J, Li H, Li YS, Zhu YG. Overexpression of SBPase enhances photosynthesis against high temperature stress in transgenic rice plants. Plant Cell Rep. 2007; 26:1635-1646. [PubMed: 17458549]

137. Liao, J-1; Zhang, H-y; Shao, X-1; Zhong, P-a; Huang, Y-j. Identification for heat tolerance in backcross recombinant lines and screening of backcross introgression lines with heat tolerance at milky stage in rice. Rice Sci. 2011; 18:279-286.

138. Senthil-Kumar M, Srikanthbabu V, Mohan Raju B, Ganeshkumar, Shivaprakash N, Udayakumar M. Screening of inbred lines to develop a thermotolerant sunflower hybrid using the temperature induction response (TIR) technique: a novel approach by exploiting residual variability. J. Exp. Bot. 2003; 54:2569-2578. [PubMed: 14565951]

139. Fouad WM, Rathinasabapathi B. Expression of bacterial L-aspartate-alpha-decarboxylase in tobacco increases beta-alanine and pantothenate levels and improves thermotolerance. Plant Mol. Biol. 2006; 60:495-505. [PubMed: 16525887]

140. Zhu Y, Wang Z, Jing Y, Wang L, Liu X, Liu Y, Deng X. Ectopic over-expression of BhHsf1, a heat shock factor from the resurrection plant Boea hygrometrica, leads to increased thermotolerance and retarded growth in transgenic Arabidopsis and tobacco. Plant Mol. Biol. 2009; 71:451-467. [PubMed: 19701723]

141. Chang CC, Huang PS, Lin HR, Lu CH. Transactivation of protein expression by rice HSP101 in planta and using Hsp101 as a selection marker for transformation. Plant Cell Physiol. 2007; 48:1098-1107. [PubMed: 17597080]

142. Yang X, Liang Z, Lu C. Genetic engineering of the biosynthesis of glycinebetaine enhances photosynthesis against high temperature stress in transgenic tobacco plants. Plant Physiol. 2005; 138:2299-2309. [PubMed: 16024688]

143. Yang X, Wen X, Gong H, Lu Q, Yang Z, Tang Y, Liang Z, Lu C. Genetic engineering of the biosynthesis of glycinebetaine enhances thermotolerance of photosystem II in tobacco plants. Planta. 2007; 225:719-733. [PubMed: 16953431] 
144. Yan K, Chen N, Qu YY, Dong XC, Meng QW, Zhao SJ. Overexpression of sweet pepper glycerol-3-phosphate acyltransferase gene enhanced thermotolerance of photosynthetic apparatus in transgenic tobacco. J. Integr. Plant Biol. 2008; 50:613-621. [PubMed: 18713430]

145. Sanmiya K, Suzuki K, Egawa Y, Shono M. Mitochondrial small heat-shock protein enhances thermotolerance in tobacco plants. FEBS Lett. 2004; 557:265-268. [PubMed: 14741379]

146. Li S, Li F, Wang J, Zhang WEN, Meng Q, Chen THH, Murata N, Yang X. Glycinebetaine enhances the tolerance of tomato plants to high temperature during germination of seeds and growth of seedlings. Plant Cell Environ. 2011; 34:1931-1943. [PubMed: 21711358]

147. Yang, J-y; Sun, Y.; Sun, A-q; Yi, S-y; Qin, J.; Li, M-h; Liu, J. The involvement of chloroplast HSP100/ClpB in the acquired thermotolerance in tomato. Plant Mol. Biol. 2006; 62:385-395. [PubMed: 16912911]

148. Fokar M, Nguyen H, Blum A. Heat tolerance in spring wheat. I. Estimating cellular thermotolerance and its heritability. Euphytica. 1998; 104:1-8.

149. O'Mahony P, Burke JJ, Oliver MJ. Identification of acquired thermotolerance deficiency within the ditelosomic series of 'Chinese Spring' wheat. Plant Physiol. Biochem. 2000; 38:243-252. 


\section{Highlights}

1. Four major thermotolerance types have been categorized.

2. Phenotyping with only one or two thermotolerance assays is not adequate for elucidating the functions of the heat stress response genes.

3. Thermotolerance diversity should be considered when study the role of genes in heat stress response.

4. Table I and II summarize the major parameters for thermotolerance phenotyping in Arabidopsis and crop plants, respectively. 
A.
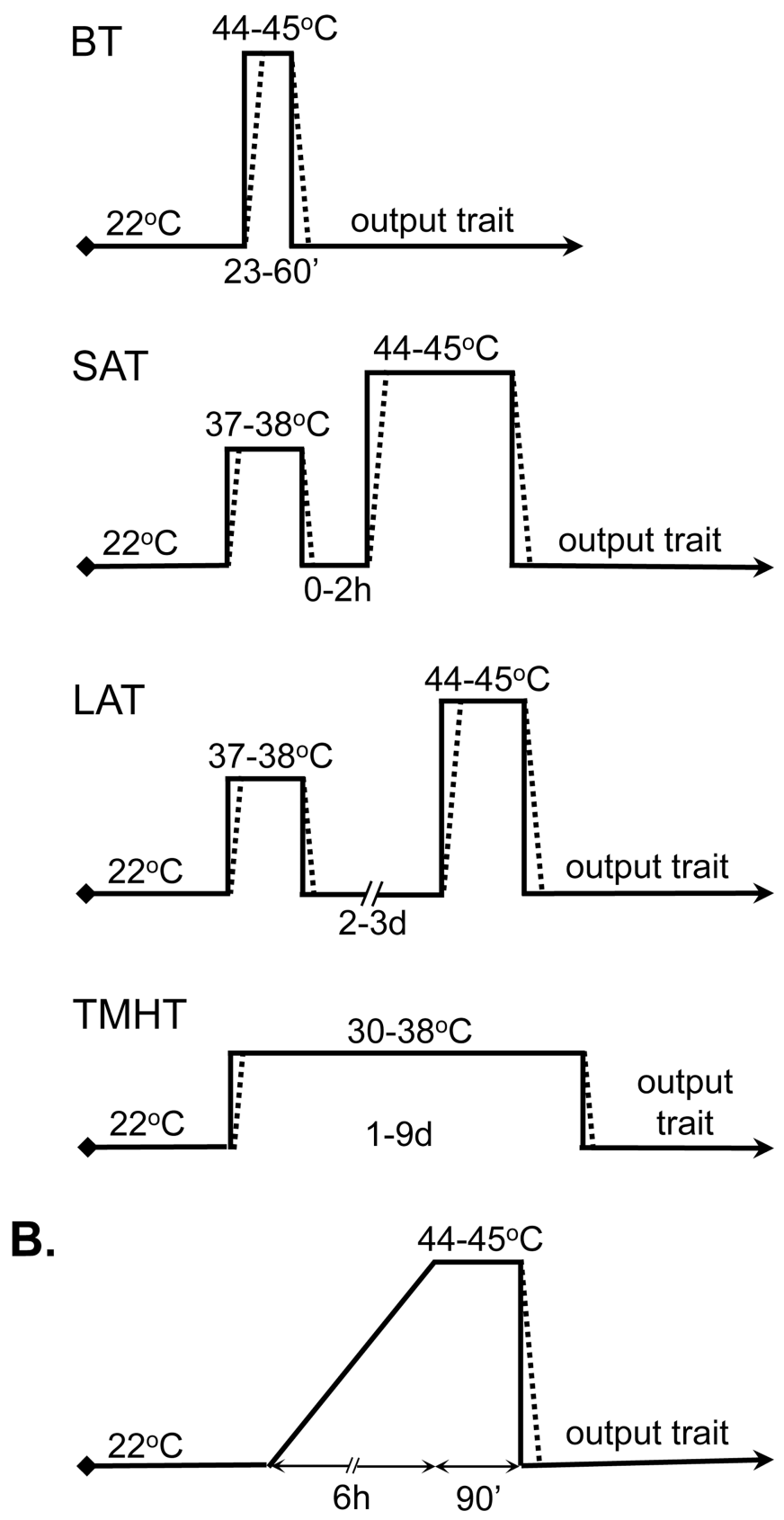

Fig. 1. Heat stress regimes used for thermotolerance phenotyping in Arabidopsis A. Schemes of heat stress regimes for four major types of thermotolerance: basal thermotolerance (BT), short-term acquired thermotolerance (SAT), long-term acquired thermotolerance (LAT), and thermotolerance to moderately high temperatures (TMHT). The schemes show temperatures that are often used in young seedlings. The temperature and duration of treatment varies depending on the exact tissue tested or experimental design used. The dashed lines indicate the time-lag between the applied temperature and the sample temperature, which vary with the heating device used. The output traits are assessed after 
various periods of incubation after the heat treatment. B. The heat stress regime for gradient acclimation is adopted from [31]. 


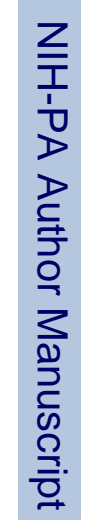

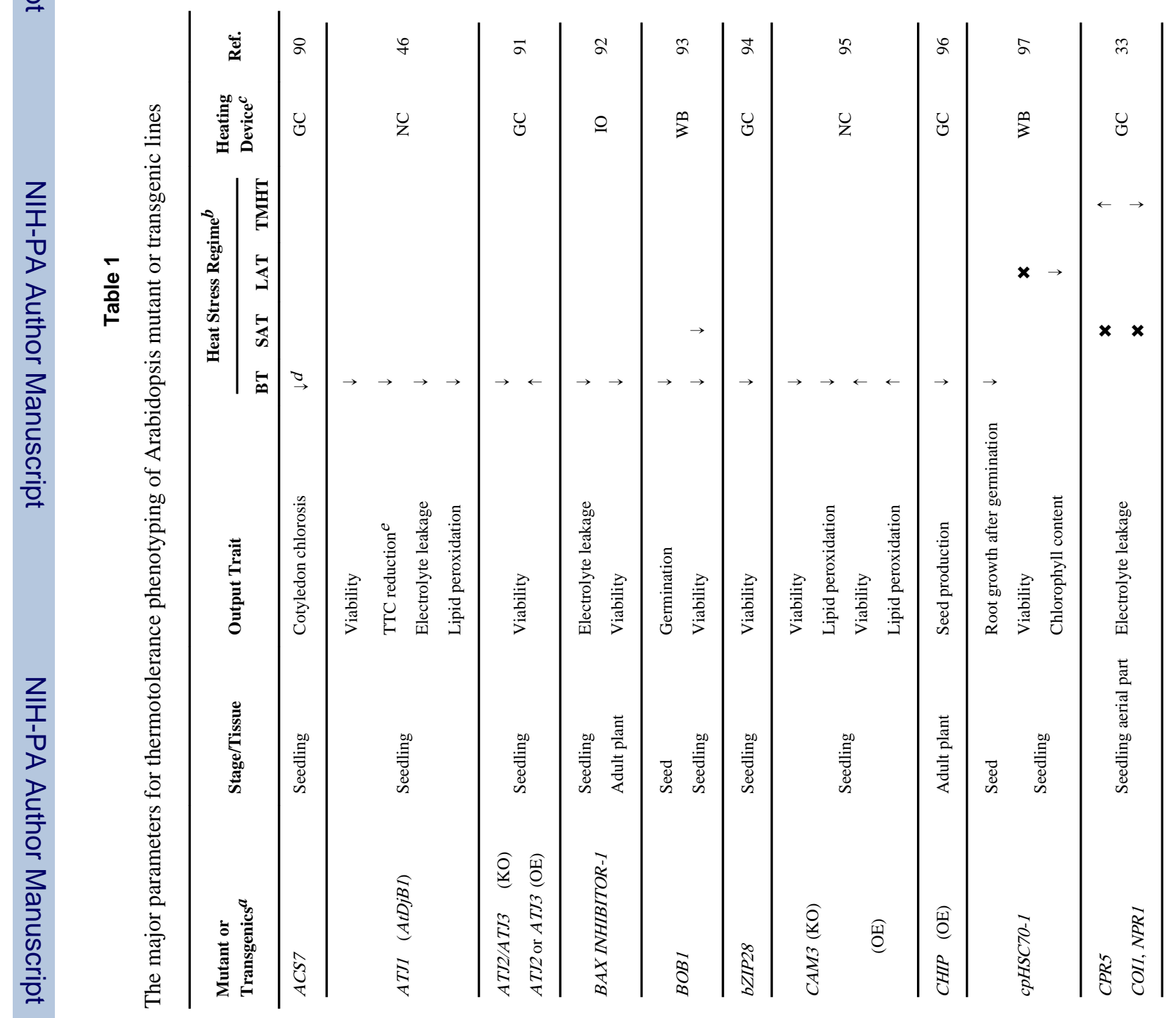




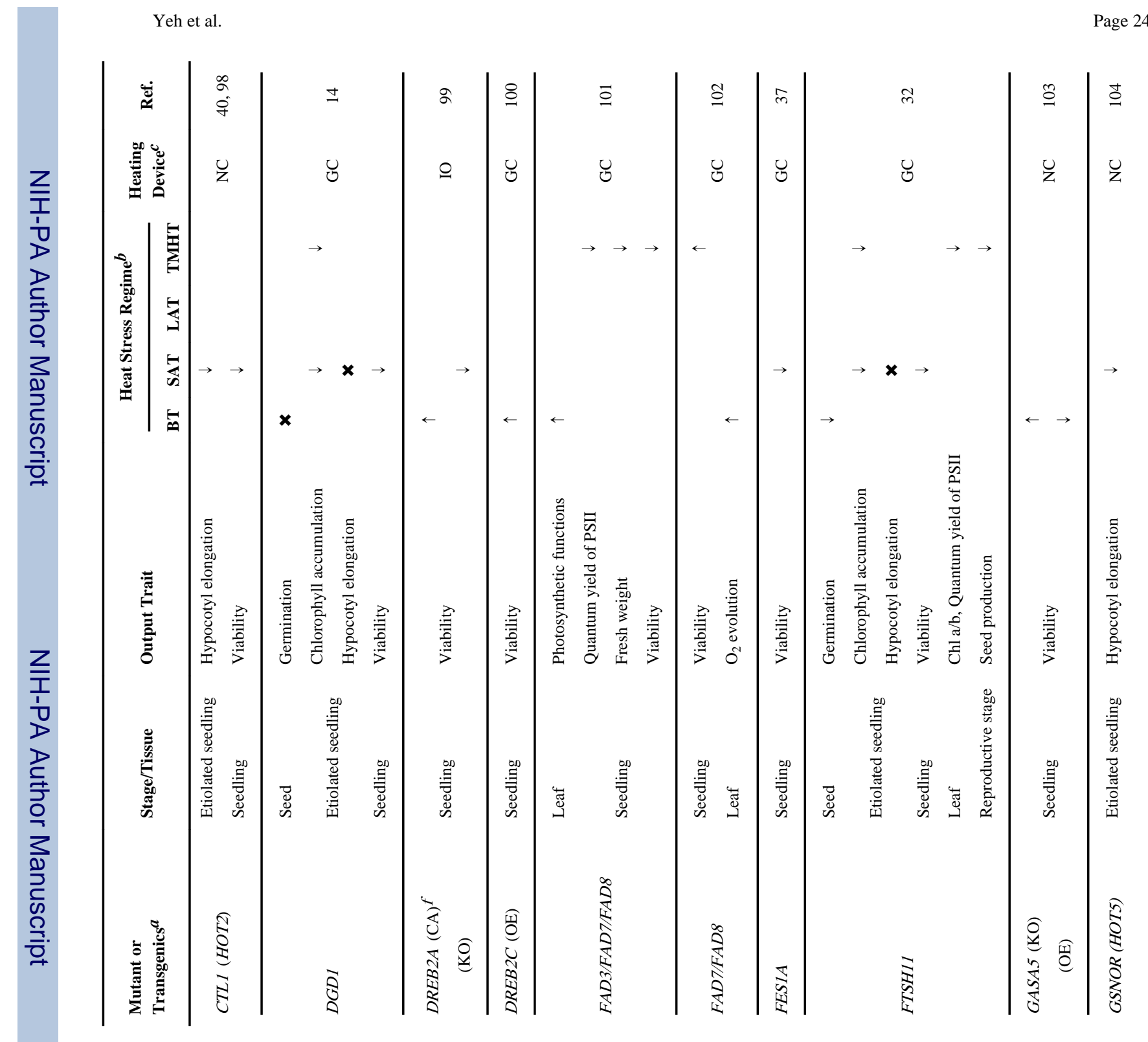

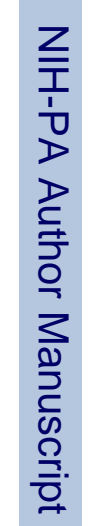




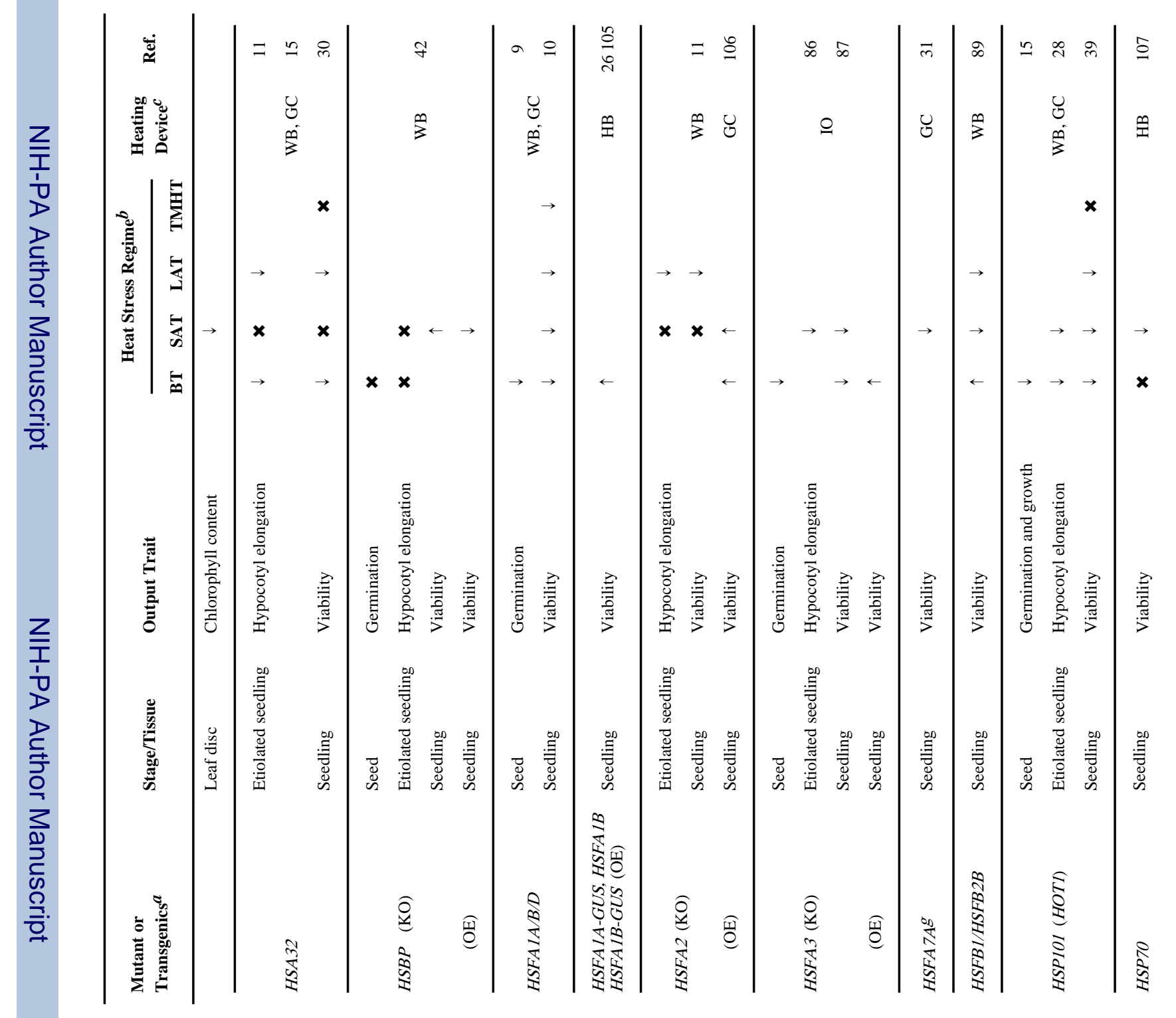

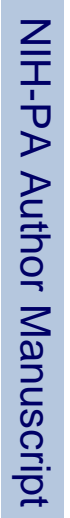


Yeh et al.

Page 26

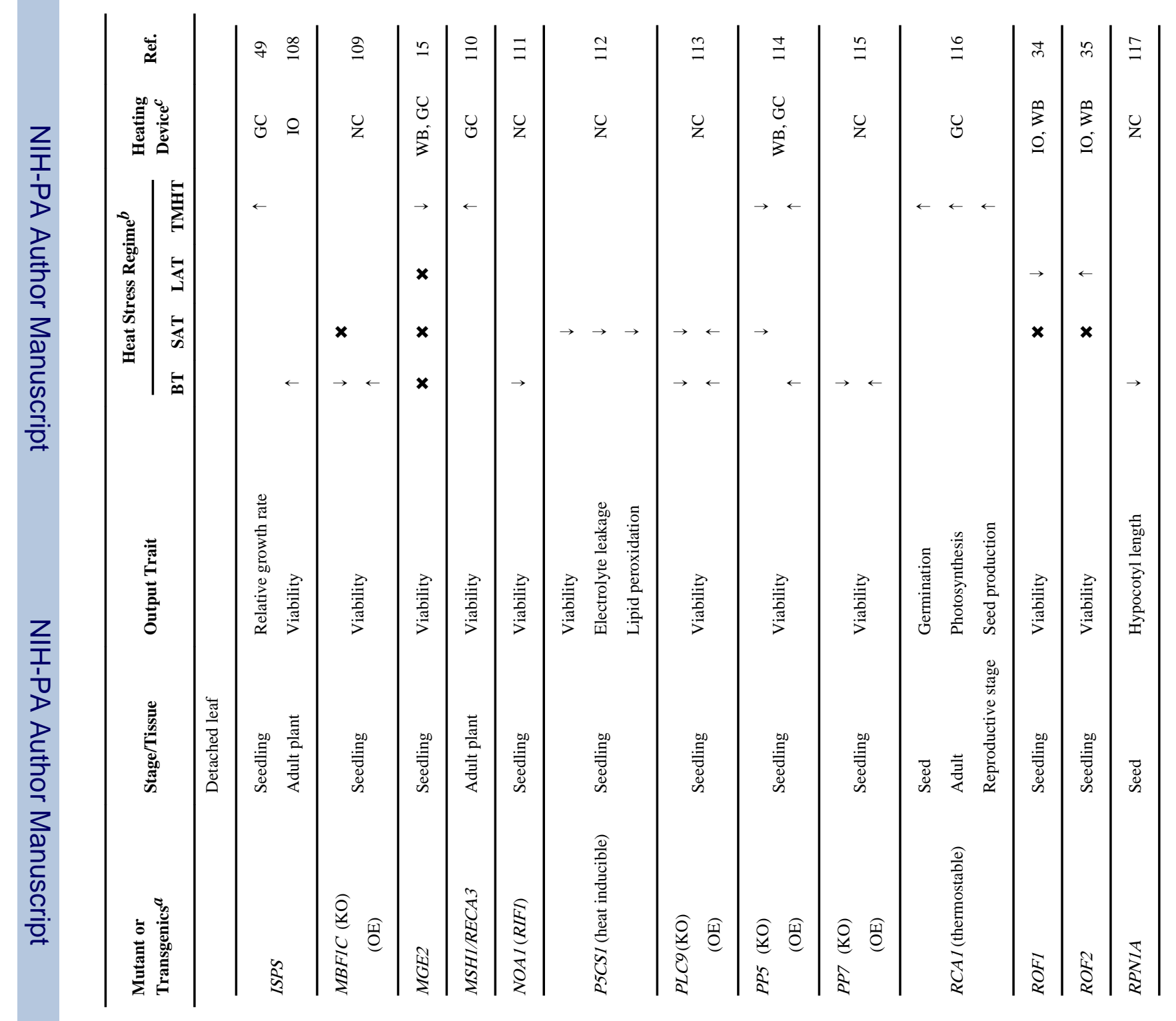

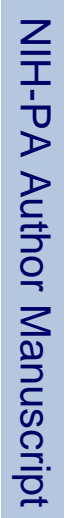




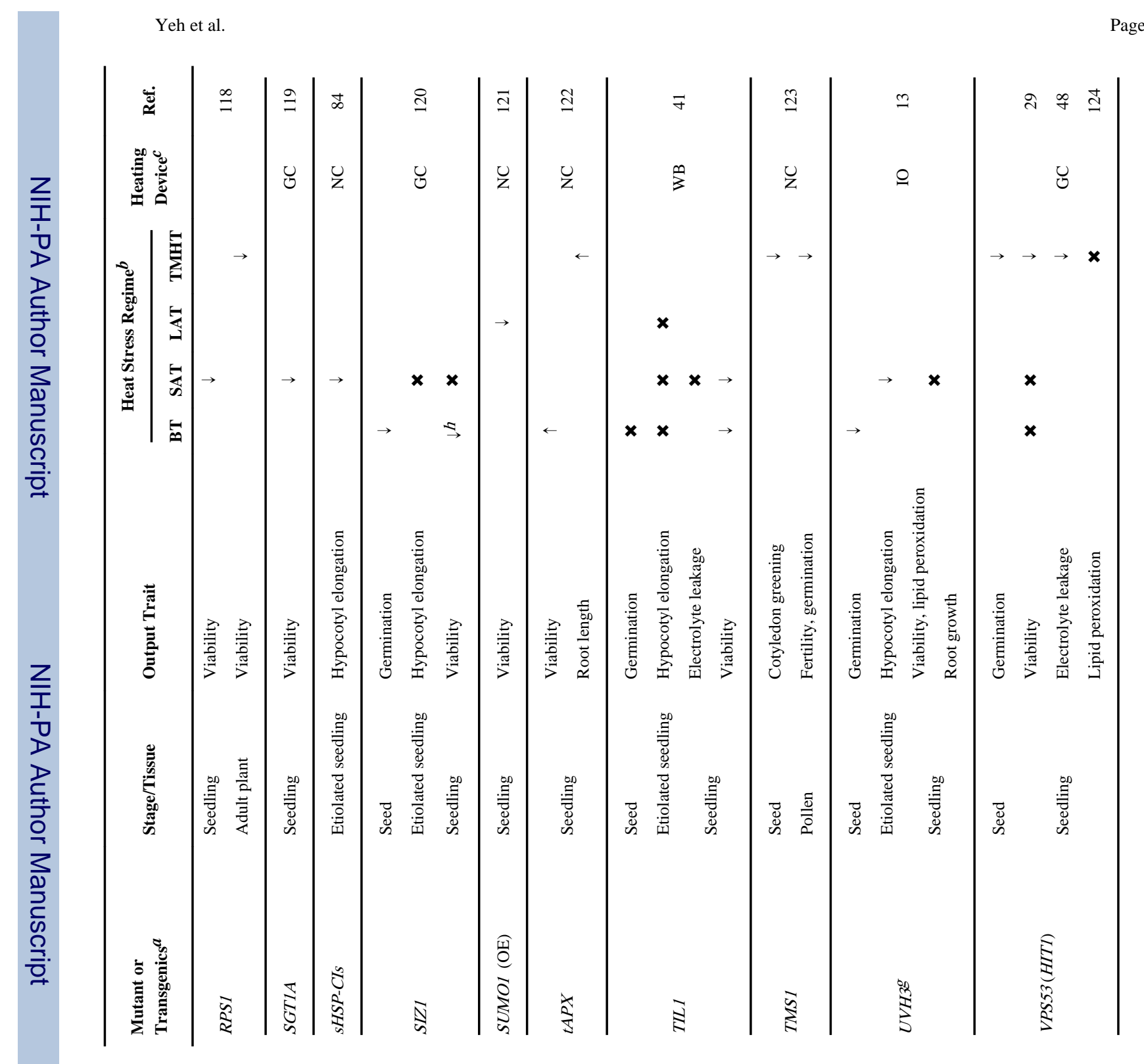

Page 27

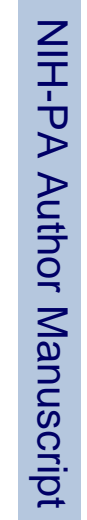




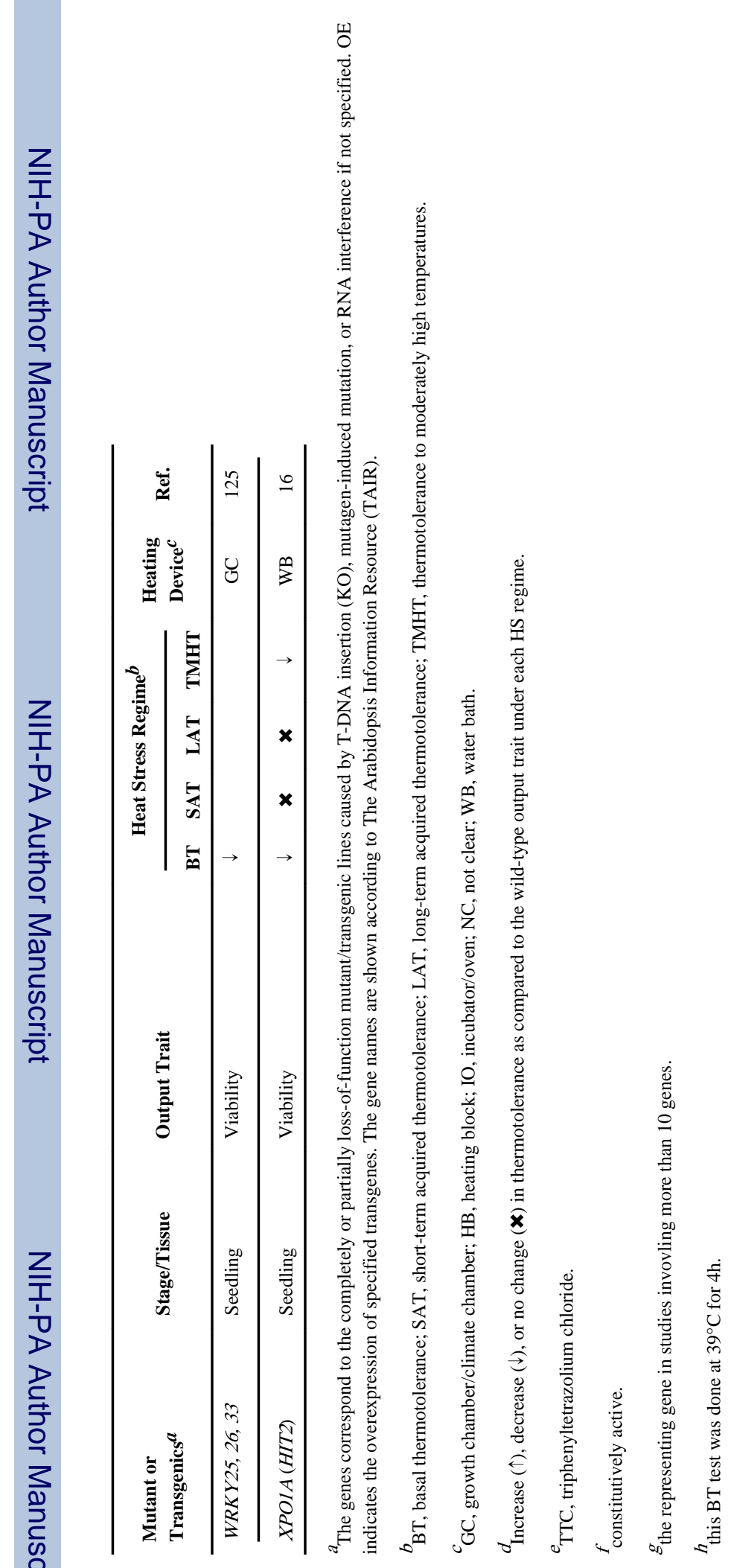

Plant Sci. Author manuscript; available in PMC 2013 October 01. 


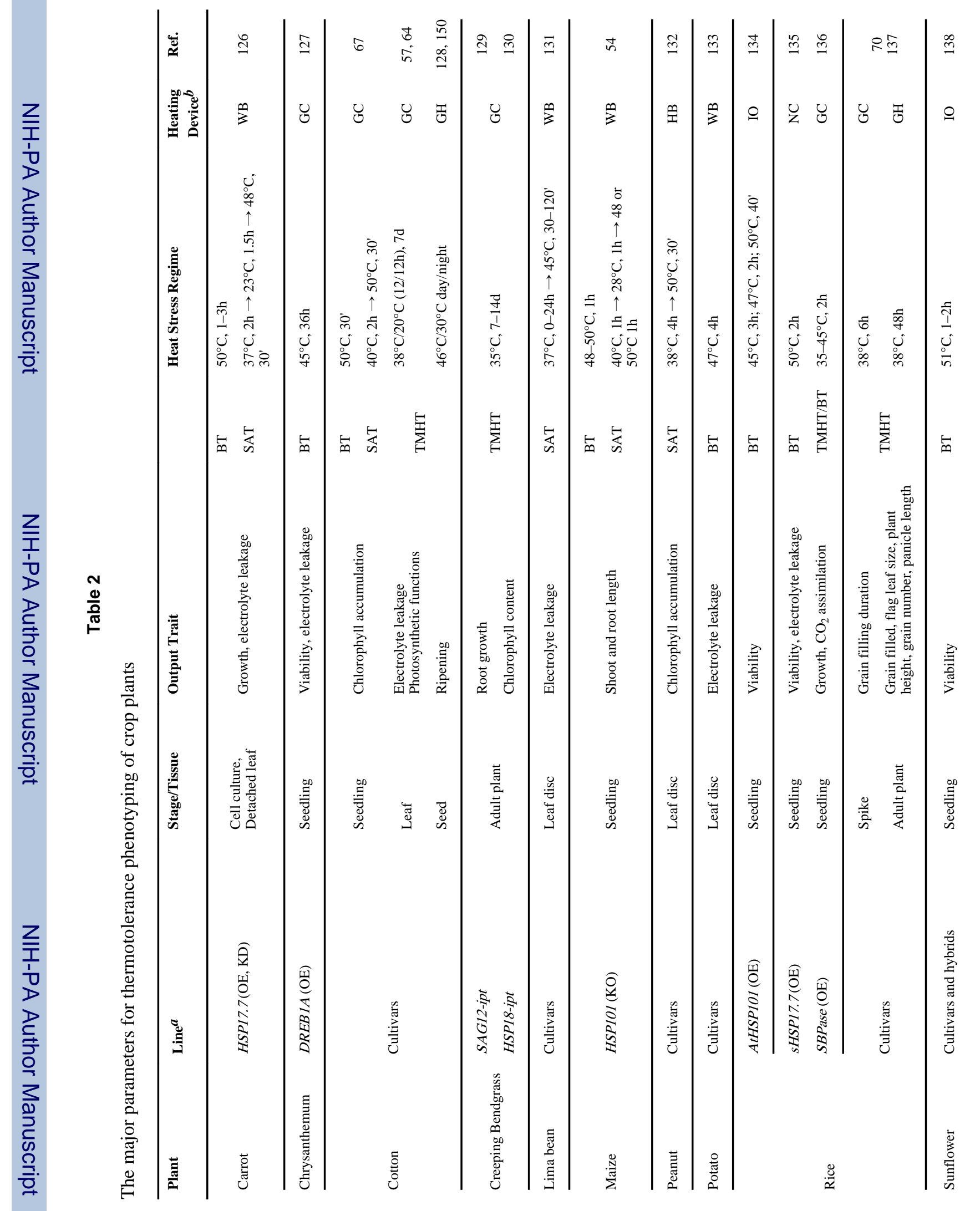


Yeh et al.

Page 30

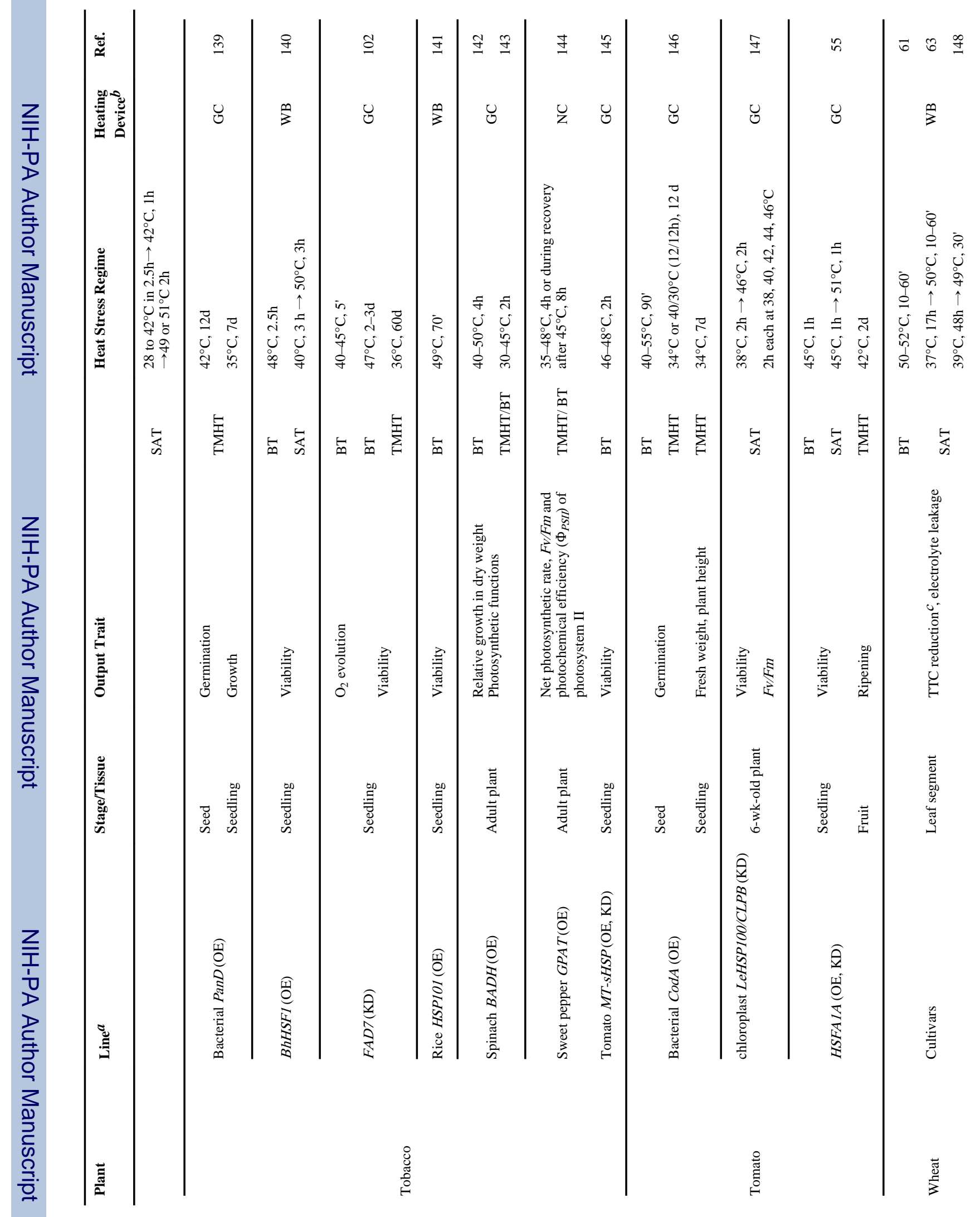

Plant Sci. Author manuscript; available in PMC 2013 October 01. 


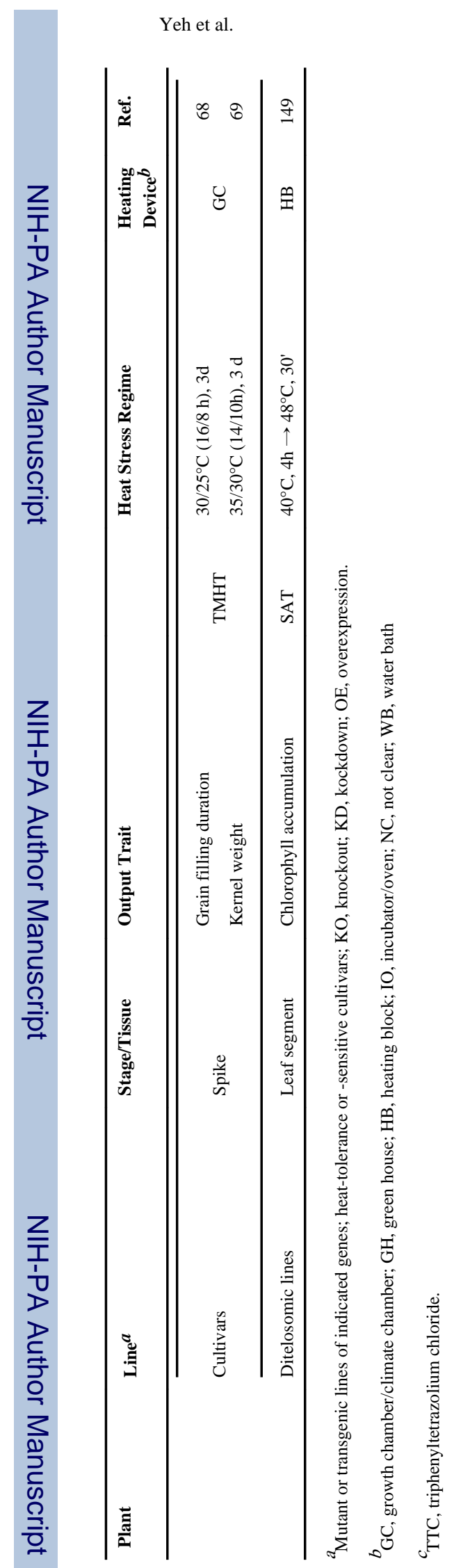

Page 31 